\title{
Credit Default of Local Public Sectors in Chinese Government-Pay PPP Projects: Evidence from Ecological Construction
}

\author{
Jie Yang, Lingchuan Song $\mathbb{D}^{D}$, and Zhongdan Xing \\ School of Management Engineering, Shandong Jianzhu University, Jinan 250101, China \\ Correspondence should be addressed to Lingchuan Song; songlc22@163.com
}

Received 13 March 2019; Accepted 25 June 2019; Published 17 July 2019

Academic Editor: Behzad Esmaeili

Copyright (c 2019 Jie Yang et al. This is an open access article distributed under the Creative Commons Attribution License, which permits unrestricted use, distribution, and reproduction in any medium, provided the original work is properly cited.

Credit is regarded as a key factor to maintain the sustainability of cooperation between public authorities and social capitals in Government-Pay Public-Private Partnership (PPP) projects. The credit default of local public sectors has become a formidable force to cause termination in several cases. The study aims to explore the critical conditions and main logics behind opportunistic behaviours through literature analysis. In this research, political performance, fiscal illusion, subjective willingness, and objective limitation are identified as four certain conditions. Additionally, the crisp-set Qualitative Comparative Analysis (csQCA) method is applied to determine the connections between conditions and the credit default in the Chinese Government-Pay PPP projects according to 15 cases from the field of ecological construction. Consequently, two combinations with complete sufficiency leading to severe extent of credit default are categorized. The configuration of political performance and fiscal illusion is dominant, thereby causing severe extent of credit default in the preimplementation link. Correspondingly, the configuration of subjective willingness, objective limitation, and nonpolitical performance is crucial in the implementation and postimplementation links. Moreover, fiscal illusion alone could be totally sufficient to lead to a termination. This research not only enriches the theoretical system on credit default of public authorities in Government-Pay PPP projects but also provides reference for all participants to forecast the potential risks especially the credit default in PPP projects.

\section{Introduction}

Over the past two decades, the Public-Private Partnership (PPP) mode has greatly contributed to the expansion of the supply of urban infrastructures and public services in China [1].

As the central public sectors (CPSs, including the State Council, Ministry of Finance, and the National Development and Reform Commission) have issued policies to constantly promote the PPP mode since 2014, the new wave of PPP rapidly emerged in China [2]. The PPP mode is widely acknowledged to help release the burden of government spending $[3,4]$, improve the quality and efficiency of infrastructures [5-8], promote the transformation of government functions, and market opening levels [9, 10]. Under these circumstances, the local public sectors (LPSs) in nearly all provinces also issued relevant guidelines and recommendations in response to CPSs [11]. Meanwhile, the risk for the credit default of LPSs has grown as PPP projects were increasingly implemented [12].
Government-Pay is one of the three subsystems according to the "Operational Guidelines for Public-Private Partnership Mode" issued by CPSs [13]. Such subsystem is also a payment version based on the Private Finance Initiative (PFI) mode of the UK [14], which has been widely accepted by LPSs. Information shows that more than $90 \%$ of PPP projects implemented in China adopted GovernmentPay or Government-and-User-Pay as the returning mechanism for the second quarter of 2018 [15]. Although CPSs started to realize the risk of abusing Government-Pay PPP projects and the huge debt pressure in the payment period to LPSs [16], the enthusiasm for Government-Pay remained because of two reasons: first, Government-Pay is in line with the public financial budget and is thus the steadiest return mechanism to meet the need of social capitals that prefer projects with less risk [17]. Second, some LPSs made unrealistic guarantees to social capitals and even disguised some unsuitable construction projects as Government-Pay PPP projects in response to CPSs with the aim to improve 
their administrative performance [18, 19]. Revenue from most of the disguised projects with poor performance and low profits may not cover the costs [12], a situation which heightens the probability of early termination and credit default. With LPSs as the resource tender, decision-maker, and market supervisor [20], the credit default of LPSs means power dissimilation and behaviour misconduct. Consequently, the sustainability of PPP projects may be breached and the reputation of LPSs may be damaged [21].

The Government-Pay PPP mode was widely used in the field of ecological construction, including water treatment, waste incineration, and sewage treatment. Compared with the User-Pay subsystem, Government-Pay (or Governmentand-User-Pay) with LPSs endorsement (which is based on local fiscal expenditure) has been recognized as the most prudent return mechanism for potential investors [17]. In terms of social capitals, the state-owned enterprises (SOE) often undertake large-scale municipal engineering construction with low benefits because of policy orientation and strong risk resistance [22]. Moreover, private enterprises (as distinguished from SOE) with the orientation of profitseeking also preferred the reliable Government-Pay approach, especially in ecological construction that considers the restrictions of risk attitude, capital scale, and market environment. These endeavours met the basic concept of PPP: "profit reasonably rather than hugely." The preference from both public sectors and social capitals led to an excess of Government-Pay PPP projects. This occurrence was an important reason for budget deficit and subsidy overruns. Consequently, public expenditure will be locked in the future [23]. The CPSs have clearly specified that "the expenditure for all of the PPP projects out of budget shall account for no more than $10 \%$ of the expenditure of the general public budget" [24]. However, LPSs could break through this rigid restriction with PPP funds or earmarks that generate the hidden danger of credit default.

Some LPSs regarded this mode as an approach to highlight political achievements and postpone government expenditures. This view arises from these characteristics of PPP projects: long duration, large investment, complicated evaluation, and limited liquidity [25]. In this case study, the credit default of LPSs in Government-Pay PPP projects is concluded into two aspects by principal-agent theory: Adverse Selection and Moral Hazard [26]. This study analyses Adverse Selection from the perspectives of political performance and fiscal illusion. Similarly, Moral Hazard can also be examined from the two aspects of subjective willingness and objective limitation.

This study seeks to explore the logic of the credit default of LPSs in Chinese Government-Pay PPP Projects and identify critical conditions through a literature review. Then, crisp-set Qualitative Comparative Analysis (csQCA) is applied to elucidate the relationship between critical conditions and the severe extent of credit default from LPSs for Chinese Government-Pay PPP Projects in ecological construction. The findings of this work not only enrich the theoretical research of credit default among stakeholders but also provide reference to regulate the behaviours of LPSs.

\section{Literature Review and Background}

2.1. Behaviours among Stakeholders in PPP Projects. Institutional framework and opportunistic behaviour are two streams used by scholars. Institutional framework could be subdivided into formal institution, informal institution, and a combination of both [27]. As a puzzle making up the formal institution in PPP projects, a contract is inevitably incomplete because of high transaction cost, bounded rationality, asymmetric information, and signalling trust [28]. Strategies used to reduce the negative implication of an incomplete contract in PPP projects include changing the form of the contract by a lottery model [29], optimizing the contract by the martingale methods [30], and designing a governmental compensation contract based on game theory [31]. Additionally, some studies in the field of informal institution in PPP projects examined mutual trust $[32,33]$, working relationship [34, 35], ethical partnership [36], and social responsibility [37]. Moreover, both formal and informal institutions could be interacted as the form of contractual and relational governance in PPP projects [38-40]. Relational governance is suggested as a compensatory part of contractual governance [41], while contractual governance may also enhance relational governance performance [42].

Opportunism is another literature stream. Most studies focused on the opportunistic behaviours of governments or social capitals, which are the key stakeholders in PPP projects. Previous research revealed that the opportunism of governments in PPP projects could be caused by the long-term contractual agreement [43], multitier hierarchy [44], and deficiency of anticorruption policies [45]. In addition, several studies explored the opportunistic behaviour of social capitals in PPP projects. Principal-agent theory was used to analyse the logic of opportunism [46], the hold-up problem, and optimal incentive mechanism of social capitals [47].

Considering the unique system of China in terms of politics, culture, and economics [48], systematic analysis remains lacking in relation to these following questions: What is the logic behind the credit default of LPSs in Chinese Government-Pay PPP projects and what are the most critical conditions?

\subsection{Promotion of Government-Pay PPP Projects in China.} Since the 1994 fiscal reform, a mismatch has emerged between expenditure responsibility and the revenue power of local governments in China [49]. Most local governments were under the pressure of spending on education, health care, and social services without corresponding fiscal transfers from the central government [50]. Thus, the "Land Finance" mode became a compensatory approach of revenue for public expenditure [51]. With this mode spread nationwide, the supplements of infrastructures were assured and debt crises also arose. In the "Post-Land Finance" era, the PPP mode could become a new financing channel for local governments [52]. The modern PPP concept was introduced to China in 2014, and the institutional framework was built using the PFI mode as reference [53]. On the one hand, the Government-Pay as the return mechanism of the 
PFI mode is appropriate for the designed institution (such as for risk allocation and value for money) in China [54]. On the other hand, in the beginning of this PPP tide, the market environment was immature. Considering the existing operation process (from UK's PFI mode) and endorsement of public sectors, the Government-Pay PPP projects could have served as the trigger to attract investment from social capitals; therefore, they helped the infrastructure market to gradually transform to a high level with the subsystem of User-Pay [53].

A massive "PPP movement" with distinctive features of "Campaign-Style Governance" has rolled out since 2014 [55] and is defined as a type of policy implementation involving extraordinary mobilization of administrative resources under political sponsorship to achieve an urgent policy goal within a required time $[56,57]$. CPSs issued relevant policies to form the flexible incentive structure with preferential support from financial subsidy [58], low interest loan, and intensive PPP funding [59]. Meanwhile, incorporating the PPP promotion effect into the scope of LPSs officials' executive performance creates a rigid constraint [60]. Thus, a bureaucratic system for promoting the PPP mode in a short time was built by the flexible incentive and rigid constraint (Figure 1).

However, task conflict exists in LPSs [61]. In line with Public Choice theory, an LPS official corresponds to the "Politician" described by G. Tullock and one with multiple political goals to achieve a public goal for social development and a private goal for personal gains $[62,63]$. On the one hand, individuals in LPSs are oriented by social values to serve public interest. On the other hand, they are also motivated by personal values to seek agent rent. In response to the call from CPSs for the enforcement of policies, LPSs had to promote the PPP mode in accordance with a Campaign-Style movement. Additionally, due to political performance improvement, officials disguised inappropriate construction projects as Government-Pay PPP projects to implement them as soon as possible. Thus, the personal goal was achieved with the execution of massive fake PPP projects (especially in the Government-Pay mode). Campaign-Style Governance [64] provided a strong monitoring and incentive mechanism within a defined period time [57]. During this time, the pressure and motivation of LPSs officials were increased, a situation which could be recognized as an opportunity to fulfil private goals instead of comprehending more PPP concepts and values $[65,66]$. Accordingly, a phenomenon of "Doing PPP in purpose not in need" emerged, with surging risk of credit default in PPP projects [67].

2.3. Path Dependence of LPSs. Institutional change is described as a consequence of changes in formal rules, in informal constraints, and in certain kinds of enforcement [27]. The process of institutional change is implied by path dependence, which, in turn, comes from the increasing return mechanisms that reinforce the direction once on a given path [68]. In infrastructure investment, this round of PPP promotion could be viewed as an institutional change from the traditional mode (represented by Government
Financing Platform mode) to the PPP mode [2]. CPSs frequently issued policies to establish and strengthen the structure of formal rules of PPP promotion. However, the change of informal constraints with noticeable time lag could hardly make rapid responses to the change of explicit and dominant formal rules. Path dependence is caused by informal constraints with vague direction and social inertia [27] (Figure 2).

Government Financing Platforms have played an important role in urbanization and economic development in China, with several potential principles [69]. First, LPSs as the dominant stakeholder of information control, resource allocation, and project approval faced few power restrictions in transactions with social capitals at their jurisdiction [70]. Second, LPSs have provided implicit guarantees for Government Financing Platforms, consequently overdrawing government credit to lend money recklessly [71]. Finally, the inertia of central planning caused the lack of market spirit in LPSs and the prevalence of the "Administration upon Profession" phenomenon.

The potential rules above make up the informal constraints of the traditional mode. Given the high transaction costs, informal constraints constitute a significant complement to formal rules with certain sunk costs [27, 72]. Moreover, LPSs are also the vested interests and the game leaders who could affect the direction of institutional change. Thus, LPSs have the motivation to make the traditional mode long lasting so as to apportion sunk costs.

As we noted above, institutional change in China's infrastructure investment could be analysed from formal rules and informal constraints. In the change of formal rules, CPSs have strong administrative power to implement a unidirectional and complete transformation process. With the rapid establishment of formal rules matching the PPP mode, LPSs eagerly turned toward PPP projects in response to CPSs. In the conversion of informal constraints, accepting the PPP mode meant abandoning the potential benefits in the traditional mode. The contradictory mentality, Campaign-Style Governance, and immature market environment linked together to create an equilibrium in the PPP promotion in China, specifically a PPP mode with Chinese characteristics (Figure 3).

This equilibrium emerged from the PPP stakeholders' temporary compromises rather than from Pareto evaluation and was consequently difficult to maintain [73].

Motivated by this background, this research seeks to investigate the key conditions that affect credit default in Government-Pay PPP projects of LPSs synergistically.

\section{Research Approach and Hypotheses Formulation}

Our research adopts a qualitative research approach. Figure 4 depicts the framework of this research. First, the literature and background related to the promotion of Chinese Government-Pay PPP projects are discussed. Second, the study identifies the conditions and formulates the hypotheses to develop a csQCA model based on 15 cases in ecological construction. Moreover, csQCA is used to analyse the 


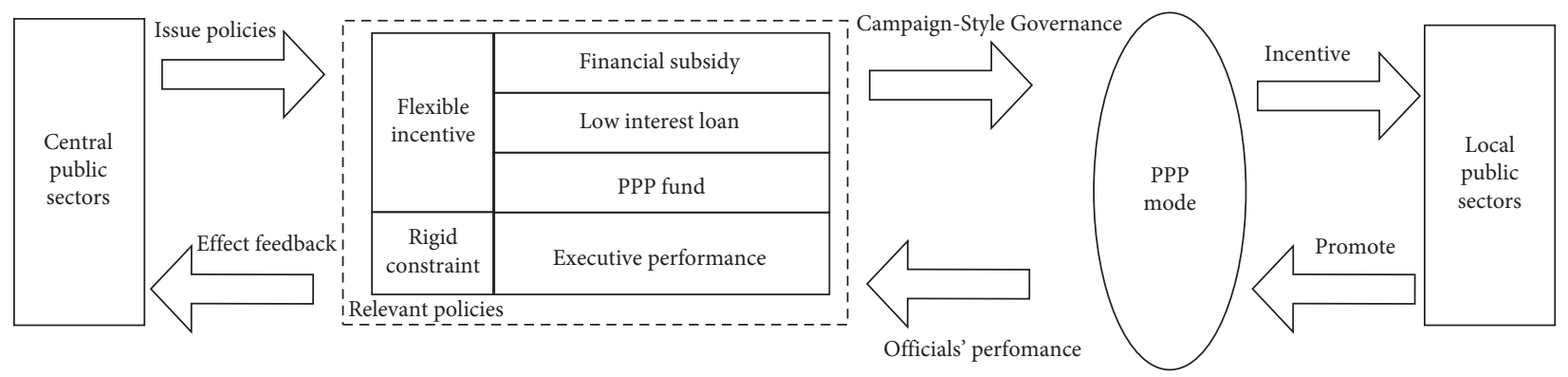

FIgURE 1: Campaign-Style Governance of the PPP movement.

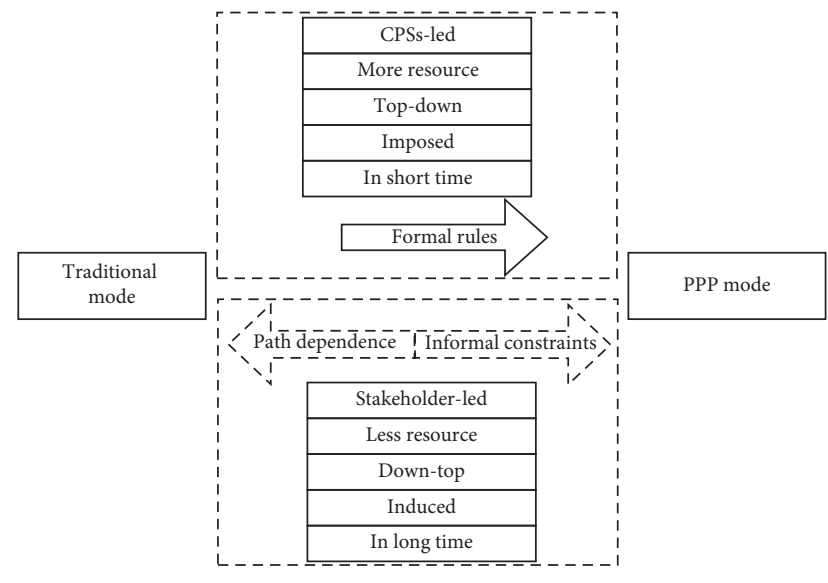

Figure 2: Process of institutional change.

relationship of the four key conditions and the severe extent of credit default in Government-Pay PPP projects. Finally, we present the result and a discussion on data analysis.

According to the literature and background analysis above, four conditions related to the credit default of LPSs in Government-Pay PPP projects are proposed in this study from Adverse Selection and Moral Hazard using principal-agent theory. Adverse Selection includes two conditions: political performance and fiscal illusion. Moral Hazard also has two conditions: subjective willingness and objective limitations. Thus, the following four hypotheses are proposed:

H1. Political performance contributes to the severe extent of credit default for LPSs in Government-Pay PPP projects.

The traditional "Tournament" competition mechanism and Campaign-Style Governance in this round of PPP promotion provide LPSs officials with strong constraints and incentives $[66,67,74]$. To meet the requirements of both public and personal goals, officials often implemented policies in a "flexible" way, including adaptive actions to fit policy goals, local conditions, and deviation from intended policy goals, due to interest conflicts or political sabotage [19]. These "flexible" behaviours could be categorized into three types:

(i) Separating the unsuitable project into several parts and then bundling some of them with the nonpublic welfare project which may have high rates of return [75] (ii) Distinguishing the low-profit public project or commercial project as a Government-Pay PPP project on the basis of endorsement from public authorities [76]

(iii) Creating repurchase agreements with social capitals in Government-Pay PPP projects [77]

Through these behaviours, LPSs developed many Government-Pay PPP projects in a short term, a development which apparently not only eased the debts pressure in response to CPSs, but also met the requirement of personal gains. Thus, the opportunism of Adverse Selection started to arise with the emergence of numerous fake PPP projects.

H2. Fiscal illusion contributes to severe extent of credit default for LPSs in Government-Pay PPP projects.

While the investment return of Government-Pay PPP projects still comes from public expenditure, such return underwent a transformation from spot payment or deferred payment in the traditional mode to instalment in the PPP mode. Extension of the payment term fully dissipated the financial pressure [54]. Public authorities are prone to believe a fiscal illusion that the PPP mode could be cheaper than the traditional mode or even be free [78]. To some extent, this mode could also be viewed as a mega-credit card which leads intergenerational inequality in bureaucracy, with moving expenditures off-budget and transferring costs on to future governments (or taxpayers) [54, 79, 80]. Some local governments have made unreasonable promises of revenue to private sectors to enhance the attractiveness of a project [81, 82]. In China, each term of public officials is regulated in five years [83], thereby causing a mismatch between the term of officials and PPP projects. Thus, future successors may face higher budgetary risks from last governors and are prone to halt the project to save transaction costs.

H3. Subjective willingness contributes to the severe extent of credit default for LPSs in Government-Pay PPP projects.

A critical difference exists between institutional change and technological change; specifically, vested interests often generate resistance in the process of institutional change [84]. LPSs officials as the vested interests in the traditional mode exhibit subjective willingness arising from power and costs. 


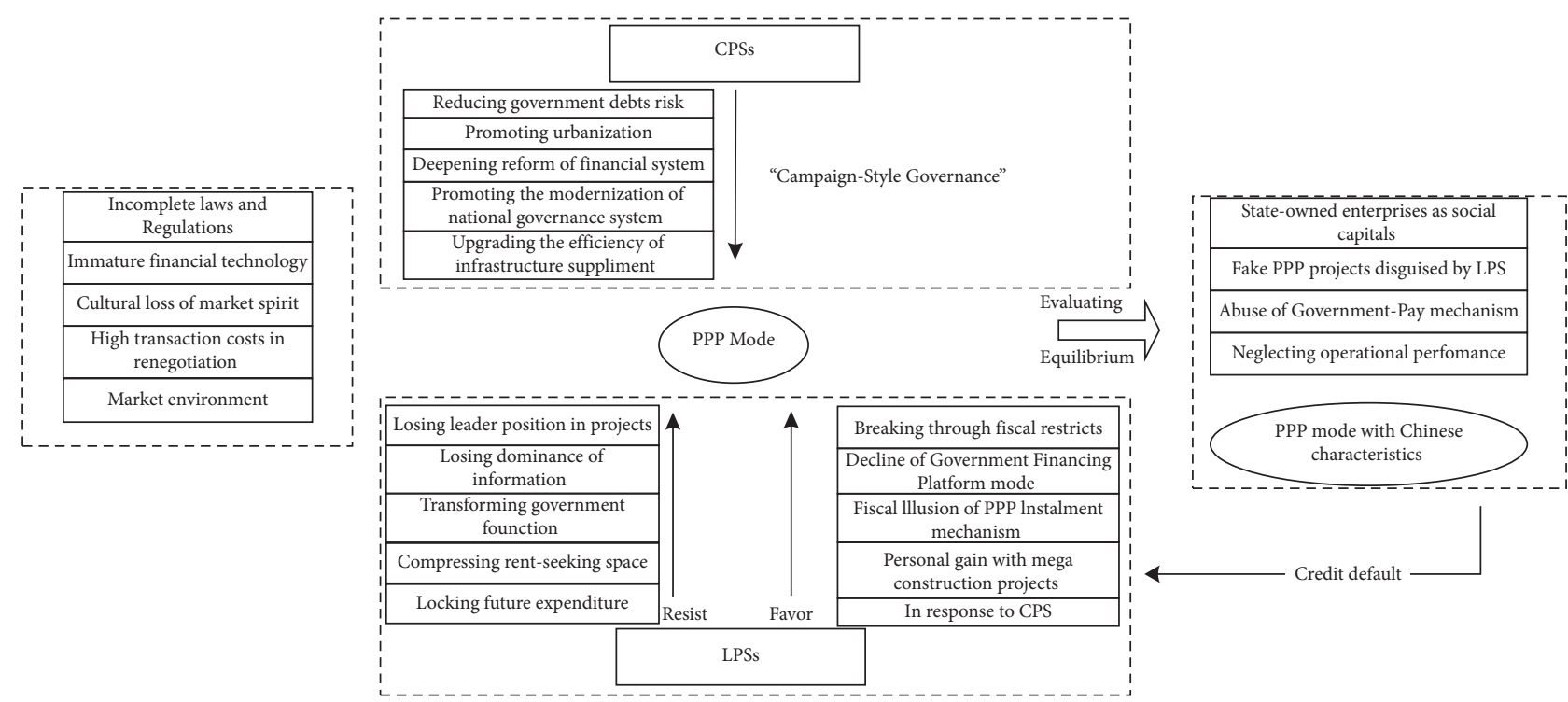

FIgURe 3: Equilibrium of China PPP promotion.

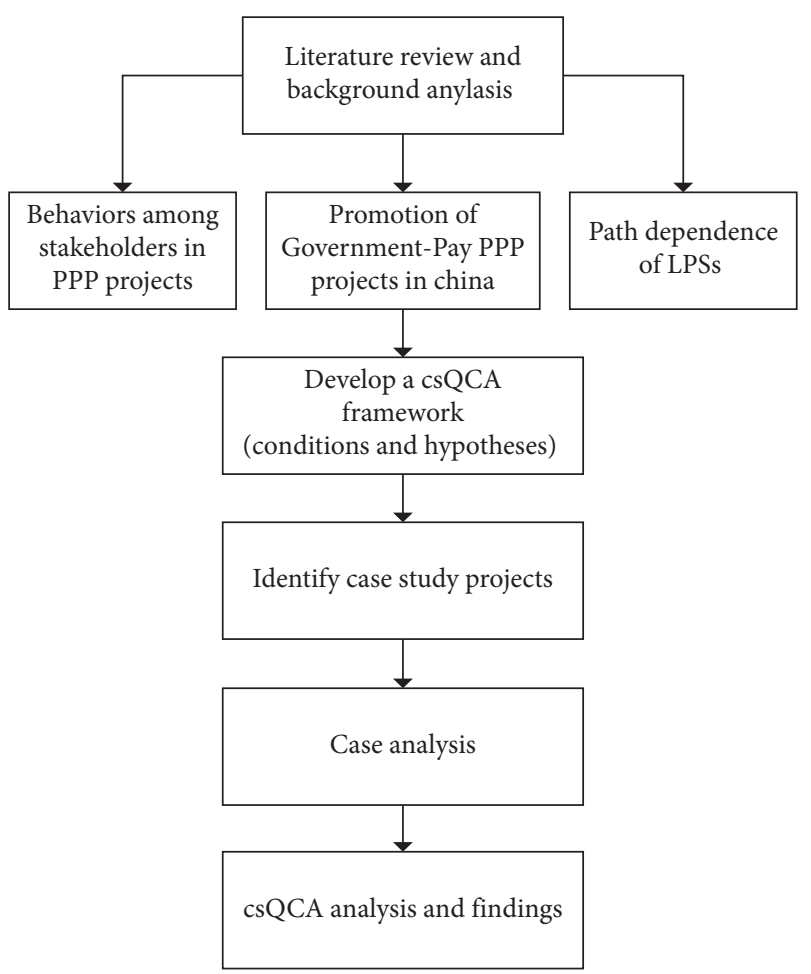

Figure 4: Diagram of the research process.

As mentioned in Section 2, LPSs, as the resource allocator, decision-maker, and information controller in the traditional mode, have the motivation of path dependence. Implementing Government-Pay PPP projects means shrinking power boundaries, increasing responsibility of future expenditure, and losing implicit benefits.

From the cost perspective, the formation and expansion of Government Financing Platforms are accompanied by huge sunk costs. That cost could be divided into these following types: (i) The cost of establishment, operation, and transformation in a new circumstance for Government Financing Platforms that involve urban investment companies, urban construction companies, and urban assets management companies

(ii) Transaction costs incurred in the signing, implementation, and information searching of contracts

(iii) Other nontangible costs for the traditional mode

Therefore, LPSs have the motivation to make the traditional mode long lasting for apportioning sunk costs.

The subjective willingness from power and costs creates the endogenous tendency of LPSs to follow the regulations, the logic of decision-making, and the behaviours under the traditional mode [85]. This tendency apparently contradicts the values of equal cooperation [86], benefit sharing, and risk allocation under the PPP mode [66].

H4. Objective limitation contributes to the severe extent of credit default for LPSs in Government-Pay PPP projects.

The deficiencies in the approval system, legal system, and LPSs professional management also limit the implementation and operation of Government-Pay PPP projects. As two critical parts in the identification phase, the quality of Value for Money (VfM) and Financial Affordability Assessment (FAA) have impacts on the performance of Government-Pay PPP projects [87]. However, VfM and FAA are gradually becoming formalistic in practice. They are just regarded by relevant participants as written procedures in formality. Moreover, the quantitative analysis of VfM relies excessively on conditional assumptions and estimated data, while qualitative analysis also entails many subjective presumptions [88]. Furthermore, the $10 \%$ expenditure limitation regulated by CPSs is not acceptable for all regions in China given the varying degrees of economic development and demand for infrastructure [89]. Additionally, LPSs lack the professional ability of renegotiating when PPP projects are under dispute. 


\section{Identification: Logic of Credit Default}

On the basis of extensive studies from industrial colleagues, this research categorizes four conditions about the logics of LPSs opportunistic behaviours.

4.1. Political Performance. Political and governance risks are always critical to PPP projects [54]. The opportunistic motivations of LPSs in Government-Pay PPP projects could be categorized into three aspects. First, during a defined period of time, LPSs are under high pressure from CPSs in the bureaucratic structure to approve or halt certain construction projects [12, 19, 82, 90-92]. Apparently, political performance is results-orientated and relies less on how LPSs finished the tasks $[19,67]$. Second, LPSs officials are regarded as "Politician" who make efforts for public affairs and also for personal gains $[62,63]$. Thus, some unsuitable Government-Pay PPP projects were implemented because of rent-seeking or corruptive actions from LPSs officials [12, 44, 93-99]. Third, public opposition in areas with inferior PPP projects could make LPSs halt the project $[1,3,100-102]$. Therefore, three logics of credit default in political performance are identified: political pressure, official corruption, and public opposition. Political pressure and corruption often take place before project implementation, and public opposition usually happens after project identification.

4.2. Fiscal Illusion. Two aspects are concluded under fiscal illusion. On the one hand, the lack of cognition about the PPP mode leads LPSs officials to assume that applying this mode could be cheaper and more efficient than the traditional pattern, especially during the period when local governments have high debts $[54,78,103,104]$. Thus, LPSs may have incorrect ideas for attracting more investment from social capitals without reasonable consideration of future expenditure [105]. On the other hand, some local authorities reach unrealistic agreements with private sectors in relation to revenue that could be difficult to fulfil $[12,82,106,107]$. The two sides above cause LPSs to fall into a fiscal illusion.

4.3. Subjective Willingness. Three aspects fall under this condition. First, the abuse of power by LPSs is still typical in China, given the overwhelming transformation from central planning to a market economy under 30 years $[12,19,82$, $91,108]$. Local authorities could intervene in the process from project design to operation without appropriate power restriction [7, 109-113]. Second, when the projects with unreasonable revenue promises went into the operation stage, LPSs had poor motivation to promptly execute their obligation for payment $[7,112]$. Third, under the change of policies and regulations, LPSs would choose to halt projects rather than make timely remedial measurements $[25,92,110,114,115]$. These three logics above stem from the path dependence on the traditional mode and make up the subjective willingness of credit default.
4.4. Objective Limitation. Under this condition, three logics are identified from the literature on government opportunistic behaviours in PPP projects. First, the poor decisionmaking in the prophase of PPP projects could increase the probability of contract implementation considering the low professional skills in market estimation, project approval, procedure process, and other preparations [92, 116, 117]. Second, the lack of operational experience causes inefficient management $[109,115,118,119]$, and LPSs need a scientific performance appraisal system as a payment basis in Government-Pay PPP projects. Finally, insufficient expertise in renegotiation could also contribute to opportunism from LPSs [120, 121]. When projects encounter unforeseen conditions, LPSs face a few dispute resolution processes to modify or renew the contract. These three logics are categorized on the basis of the timeline of project implementation.

Certain logics under each condition were identified based on the literature review (Table 1). All these conditions could be divided into two aspects according to the processes of the links (Figure 5). That is, political performance and fiscal illusion often occur in the preimplementation period, and subjective willingness and objective limitation occur in the other period.

\section{Research Method: Crisp-Set Qualitative Comparative Analysis}

5.1. Introduction to csQCA. Qualitative Comparative Analysis (QCA) was proposed by Charles Ragin in 1987 [122]. It could be regarded as a combination of qualitative and quantitative analysis based on case and variable [123]. QCA makes a comparison among certain cases to identify the difference and similarity. Additionally, this method could be specifically divided into crisp-set Qualitative Comparative Analysis (csQCA) and fuzzy-set Qualitative Comparative Analysis (fsQCA). Comparing csQCA, fsQCA could break through the limitation of binary value. However, considering the specific logics have been concluded under four conditions in section four, it is obvious to confirm the binary value. Thus, csQCA is applied in this paper. One of the characteristics of csQCA is that it could identify multiple conjunctural causation [123]. The steps of applying csQCA [124] are shown in Figure 6.

5.2. Data Collection. Following the research by Axel Marx in 2013 [124], 5\% was set as the threshold in this manuscript. Thus, 15, as the number of cases, is suitable under the four conditions for an acceptable benchmark.

5.2.1. Case Selection. Based on typical case studies on critical factors, this research was implemented in the following three steps: (1) case selection according to specific criteria, (2) data collection and analysis, and (3) discussion of the identified factors.

Considering that Government-Pay is a common mechanism applied widely in Chinese ecological construction, certain cases were examined in our manuscript through the following criteria: 
TABLE 1: Logic of credit default for LPSs in Government-Pay PPP projects.

\begin{tabular}{lccc}
\hline Political performance & Fiscal illusion & Subjective willingness & Objective limitation \\
\hline M1: political pressure & M4: poor cognition & M6: abuse of power & M9: poor decision-making procedure \\
M2: official corruption & M5: unreasonable guarantee & M7: repudiation of payment & M10: lack of operational experience \\
M3: public opposition & & M8: response to policy changes & M11: insufficient expertise in renegotiation \\
\hline
\end{tabular}
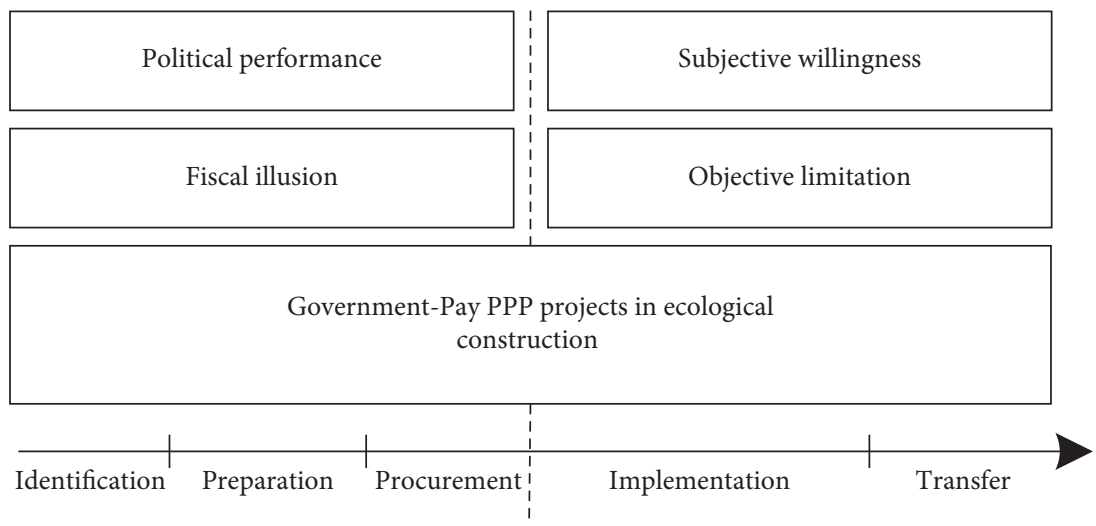

FIGURE 5: Distribution of each condition according to the processes of links.

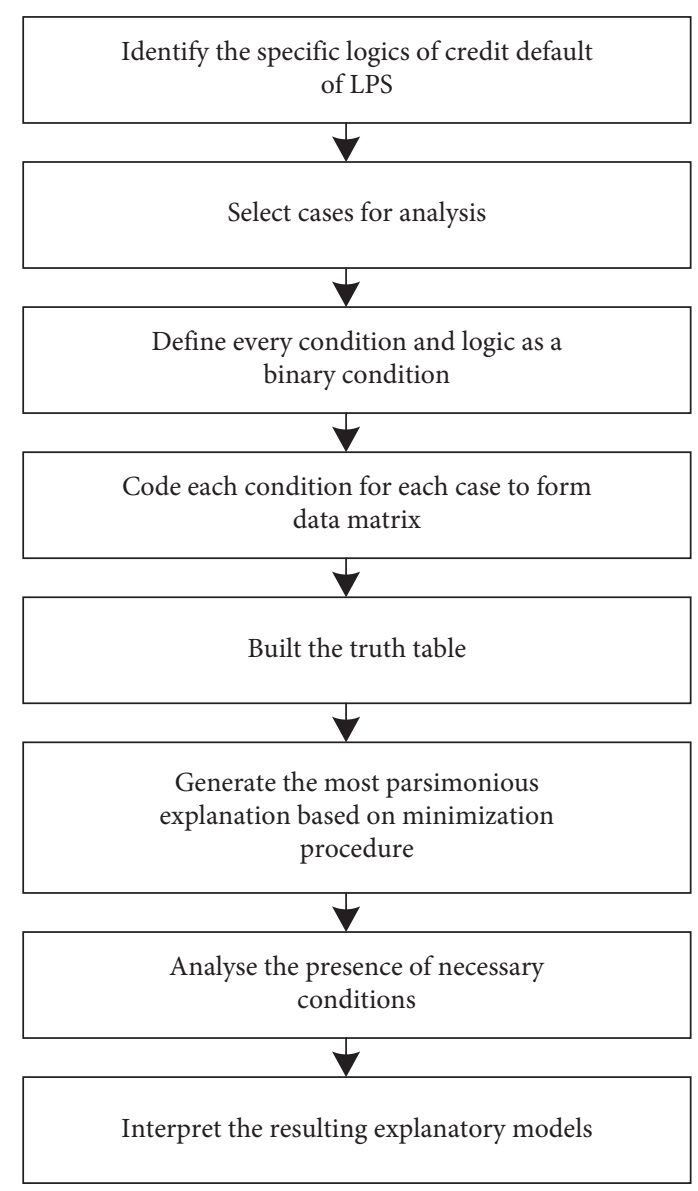

Figure 6: Steps of applying csQCA.

(i) All selected cases are typical cases based on the payment mechanism of Government-Pay or Government-and-User-Pay (ii) All selected cases suffered from credit default by LPSs

(iii) All selected cases are from fields of water plants, waste incineration plants, and sewage treatment

(iv) Participants from all selected cases are available to contact and were willing to cooperate with the authors for the study

Consequently, 15 sample cases were identified: (1) Lianjiang Tangshan Water Plant, (2) Shandong Zhonghua Project, (3) Tianjin Shuanggang Waste Incineration Plant, (4) Western Qinhuangdao Waste Incineration Plant, (5) Wuxi Xidong Waste Incineration Plant, (6) Beijing Liulitun Waste Incineration Plant, (7) Kunming Wuhua Waste Incineration Plant, (8) Qingdao Veolia Sewage Treatment Project, (9) Changzhou Hengshanqiao Sewage Treatment Project, (10) Changchun Huijin Sewage Treatment Project, (11) Wuhan Tangxuhu Sewage Treatment Project, (12) Shenyang no. 9 Water Plant, (13) Hancheng Sewage Treatment Project, (14) Luoyang Sewage Treatment Project, and (15) Muping Waste Incineration Plant. Tables 2 and 3 list information on all selected cases.

5.2.2. Case Collection. Basic information on the 15 selected cases was collected from various sources, including internal publications, annual reports, academic databases, the China PPP Center, and industry news. Given the limitation of approaches for searching data and because certain details of the Government-Pay PPP contracts cannot be disclosed by public authorities because of commercial confidentiality, limited controversial information may be identified and will be examined in future research.

5.2.3. Data of Interview and Questionnaire Survey Collection. Previous studies indicate the data collection of csQCA is implemented through interviews or questionnaire surveys. 
TABLE 2: General information on 15 cases from ecological construction.

\begin{tabular}{|c|c|c|c|c|}
\hline Number & Project & $\begin{array}{l}\text { Contract } \\
\text { period }\end{array}$ & $\begin{array}{c}\text { Extent of } \\
\text { Government-Pay }\end{array}$ & Levels of credit default \\
\hline 1 & Lianjiang Tangshan Water Plant & 30 years & Total & Bought back by the government in 2009 \\
\hline 2 & Shandong Zhonghua Project & 20 years & Partial & Revenue declined since 2002 \\
\hline 3 & Tianjin Shuanggang Waste Incineration Plant & 22 years & Total & Bought back by the government in 2006 \\
\hline 4 & Western Qinhuangdao Waste Incineration Plant & Uncertain & Total & $\begin{array}{l}\text { Halted temporarily by the government in } \\
\qquad 2011\end{array}$ \\
\hline 5 & Wuxi Xidong Waste Incineration Plant & Uncertain & Total & $\begin{array}{l}\text { Halted temporarily by the government in } \\
\qquad 2011\end{array}$ \\
\hline 6 & Beijing Liulitun Waste Incineration Plant & Uncertain & Total & $\begin{array}{l}\text { Halted temporarily by the government in } \\
\qquad 2011\end{array}$ \\
\hline 7 & Kunming Wuhua Waste Incineration Plant & 30 years & Partial & $\begin{array}{l}\text { Social capitals withdrew investment in } \\
\qquad 2006\end{array}$ \\
\hline 8 & Qingdao Veolia Sewage Treatment Project & 25 years & Partial & Social capitals withdrew investment in 2014 \\
\hline 9 & $\begin{array}{c}\text { Changzhou Hengshanqiao Sewage Treatment } \\
\text { Project }\end{array}$ & 30 years & Partial & Government took over temporarily in 2011 \\
\hline 10 & Changchun Huijin Sewage Treatment Project & 25 years & Partial & Bought back by the government in 2005 \\
\hline 11 & Wuhan Tangxuhu Sewage Treatment Project & 20 years & Partial & Bought back by the government in 2004 \\
\hline 12 & Shenyang No. 9 Water Plant & 20 years & Partial & Bought back by the government in 2006 \\
\hline 13 & Hancheng Sewage Treatment Project & 30 years & Total & Halted by the government in 2018 \\
\hline 14 & Luoyang Sewage Treatment Project & 20 years & Total & Halted by the government in 2018 \\
\hline 15 & Muping Waste Incineration Plant & 30 years & Total & Halted by the government in 2018 \\
\hline
\end{tabular}

TABLE 3: General information on 15 cases from ecological construction.

\begin{tabular}{|c|c|c|c|c|c|}
\hline Number & Project & $\begin{array}{l}\text { Contract } \\
\text { period }\end{array}$ & $\begin{array}{l}\text { Investment } \\
\text { (RMB) }\end{array}$ & $\begin{array}{c}\text { Data } \\
\text { source }\end{array}$ & Brief information \\
\hline 1 & $\begin{array}{c}\text { Lianjiang Tangshan Water } \\
\text { Plant }\end{array}$ & $1997-2027$ & 130 million & {$[1,125]$} & $\begin{array}{l}\text { (i) Actual demand and water price were much lower } \\
\text { than the contracted level and the contract may be lost. } \\
\text { The water plant was forced to be idle. }\end{array}$ \\
\hline 2 & Shandong Zhonghua Project & 1997-2017 & 17.6 million & {$[119,126]$} & $\begin{array}{l}\text { (i) Pricing standards approved by LPSs made it difficult } \\
\text { to meet the promised level, and LPSs failed to fulfil the } \\
\text { uniqueness of the project in the local market. }\end{array}$ \\
\hline 3 & $\begin{array}{l}\text { Tianjin Shuanggang Waste } \\
\text { Incineration Plant }\end{array}$ & $2013-2035$ & 580 million & {$[119,127]$} & $\begin{array}{l}\text { (i) LPSs were committed to provide subsidies, but the } \\
\text { amount of the subsidies promised was not defined } \\
\text { clearly. Moreover, toxic gases from waste incineration } \\
\text { caused public opposition. }\end{array}$ \\
\hline 4 & $\begin{array}{l}\text { Western Qinhuangdao Waste } \\
\text { Incineration Plant }\end{array}$ & $2008-2038$ & 220 million & [128] & $\begin{array}{l}\text { (i) The public objected to the project and reported that } \\
\text { the environmental impact report may be fraudulent. } \\
\text { LPSs revoked the environmental impact report. }\end{array}$ \\
\hline 5 & $\begin{array}{l}\text { Wuxi Xidong Waste } \\
\text { Incineration Plant }\end{array}$ & $2008-2028$ & 140 million & [129] & $\begin{array}{l}\text { (i) Public opposition arose after the construction stage } \\
\text { was finished. LPSs shirked their responsibilities and did } \\
\text { not provide a satisfactory explanation. Moreover, media } \\
\text { and social organizations misled the public. The project } \\
\text { had to be halted. }\end{array}$ \\
\hline 6 & $\begin{array}{l}\text { Beijing Liulitun Waste } \\
\text { Incineration Plant }\end{array}$ & $2006-2026$ & 126 million & {$[130]$} & $\begin{array}{l}\text { (i) The project was meant to be implemented } 15 \text { years } \\
\text { ago. Many residents around the planned location and } \\
\text { thousands of people opposed it. }\end{array}$ \\
\hline 7 & $\begin{array}{l}\text { Kunming Wuhua Waste } \\
\text { Incineration Plant }\end{array}$ & $2003-2033$ & 320 million & {$[127,131]$} & $\begin{array}{l}\text { (i) It was difficult to collect the waste fee. In addition, } \\
\text { LPSs and the SPV were not in agreement in terms of } \\
\text { adjusting the waste disposal fee. }\end{array}$ \\
\hline 8 & $\begin{array}{l}\text { Qingdao Veolia Sewage } \\
\text { Treatment Project }\end{array}$ & $2003-2038$ & 171 million & {$[119,132]$} & $\begin{array}{l}\text { (i) LPSs had limited understanding of the PPP and the } \\
\text { frequent changes in attitude towards the project led to } \\
\text { long contract negotiations. Moreover, the LPSs also } \\
\text { promised an unrealistic rate of return. }\end{array}$ \\
\hline 9 & $\begin{array}{l}\text { Changzhou Hengshanqiao } \\
\text { Sewage Treatment Project }\end{array}$ & $2005-2035$ & 60 million & {$[1,133]$} & $\begin{array}{l}\text { (i) The project closed several times and caused pollution } \\
\text { through the sewage from the pipe network overflow. } \\
\text { Considering the public opposition, LPSs shut it down } \\
\text { temporarily. }\end{array}$ \\
\hline
\end{tabular}


TABLE 3: Continued.

\begin{tabular}{|c|c|c|c|c|c|}
\hline Number & Project & $\begin{array}{l}\text { Contract } \\
\text { period }\end{array}$ & $\begin{array}{c}\text { Investment } \\
\text { (RMB) }\end{array}$ & $\begin{array}{c}\text { Data } \\
\text { source }\end{array}$ & Brief information \\
\hline 10 & $\begin{array}{l}\text { Changchun Huijin Sewage } \\
\text { Treatment Project }\end{array}$ & $2000-2020$ & 200 million & {$[1,134]$} & $\begin{array}{l}\text { (i) LPSs reneged on the agreement and refused to pay for } \\
\text { SPV, thereby causing them to be charged in } 2003 \text {. }\end{array}$ \\
\hline 11 & $\begin{array}{l}\text { Wuhan Tangxuhu Sewage } \\
\text { Treatment Project }\end{array}$ & $2001-2021$ & 90 million & {$[1]$} & $\begin{array}{c}\text { (i) LPSs failed to accomplish promised work (such as } \\
\text { supporting pipe network construction and sewage fee } \\
\text { charge). The project was terminated by government } \\
\text { buyback. }\end{array}$ \\
\hline 12 & Shenyang No. 9 Water Plant & 1996-2016 & 160 million & {$[1,135]$} & $\begin{array}{l}\text { (i) The agreed rate of return on investment was } \\
\text { unreasonable, with } 18.50 \% \text { in the first } 2-4 \text { years, } 21 \% \text { in } \\
\text { the } 5 \text { th to } 14 \text { th year, and } 11 \% \text { in the } 15 \text { th to } 20 \text { th year. } \\
\text { The project was finally terminated by LPSs. }\end{array}$ \\
\hline 13 & $\begin{array}{c}\text { Hancheng Sewage Treatment } \\
\text { Project }\end{array}$ & 2014-2044 & 931 million & {$[136]$} & $\begin{array}{l}\text { (i) The construction period is } 10 \text { years, and the project } \\
\text { covered an area of } 21751 \mathrm{~m}^{2} \text {. The project was terminated } \\
\text { by CPSs in } 2018 \text { due to poor decision-making process. }\end{array}$ \\
\hline 14 & $\begin{array}{c}\text { Luoyang Sewage Treatment } \\
\text { Project }\end{array}$ & $2015-2035$ & 190 million & {$[137]$} & $\begin{array}{l}\text { (i) The project could process } 20 \mathrm{kt} \text { of sewage daily and } \\
\text { was terminated by the Ministry of Finance in } 2018 \text { due to } \\
\text { poor decision-making process. }\end{array}$ \\
\hline 15 & $\begin{array}{c}\text { Muping Waste Incineration } \\
\text { Plant }\end{array}$ & $2012-2042$ & 428 million & {$[137]$} & $\begin{array}{l}\text { (i) The project covered an area of } 66,600 \mathrm{~m}^{2} \text {. It could } \\
\text { process } 800 \mathrm{t} \text { of municipal solid waste daily and was } \\
\text { terminated by the Ministry of Finance in } 2018 \text { due to } \\
\text { poor decision-making process. }\end{array}$ \\
\hline
\end{tabular}

Perceptual feelings can be determined through communications, and rational and quantitative data should be obtained from the questionnaire [138-141].

We referenced and improved the research process of Ahuja and applied a five-point Likert scale from 1 (strongly disagree) to 5 (strongly agree), thereby improving the accuracy and objectivity of the original data [123]. Thus, certain conditions for each case could be identified by confirming the existence of corresponding logics under each condition shown in Table 1.

Data in this research came from two steps. First, we selected 42 interviewees from the parties in the 15 cases, including private sector, LPSs, and experts from consultancy. Then, we confirmed the identity of our interviewees through a brief communication on the phone, through e-mails, and via WeChat (a social media chat app in China). We also invited our interviewees to complete the questionnaire survey through several reminders. This data collection process lasted for two months from September to October 2018. The respondent demographics and questionnaire items are shown in Table 4 and Appendix 1 in Supplementary Materials, respectively.

5.3. Variables: Identification of Conditions. In this research, a binary value of 1 is assigned to a case if one or more than one logics are presented under each condition. Conversely, a binary value of 0 is assigned to a case if no logic is presented under each condition. The binary values of the conditions are described below:

(i) Political performance was assigned with the binary value of 1 if the logics occurred within this aspect and 0 otherwise

(ii) Fiscal illusion was assigned with the binary value of 1 if the logics occurred within this aspect and 0 otherwise (iii) Subjective willingness was assigned with the binary value of 1 if the logics occurred within this aspect and 0 otherwise

(iv) Objective limitation was assigned the binary value of 1 if the logics occurred within this aspect and 0 otherwise

Moreover, we aimed not only to explore the connection between each condition and credit default of LPSs in ecological projects, but also to ascertain the relationship between the severe extent of credit default and these conditions. Considering the different levels of credit default by LPSs, this manuscript assigns the binary value of 1 if the case with severe extent of credit default involves government buyback, social capitals withdrawing investment, and government halting the project. Similarly, a binary value of 0 was assigned for the common extent of credit default, including revenue decline, government halting the project temporarily, and government taking over temporarily.

Additionally, the answers that presented values greater than or equal to 4 were assigned a value of 1 and those that presented values less than or equal to 3 were assigned a value of 0 [142].

Tables 5 and 6 reveal the results of each case under each logic of credit default by LPSs in Chinese Government-Pay PPP projects.

Thus, the csQCA data matrix based on computing the compatibility of 15 cases under 11 logics is identified (Table 7).

\section{Analysis}

6.1. Analysis on Truth Table. The truth table shown in Table 8 represents the relationship between selected cases, four conditions, and levels of credit default. All cases with 
TABle 4: Respondent demographics.

\begin{tabular}{|c|c|c|}
\hline Type & Frequency & Percentage \\
\hline \multicolumn{3}{|l|}{ Gender } \\
\hline Male & 37 & 88.10 \\
\hline Female & 5 & 11.90 \\
\hline \multicolumn{3}{|l|}{ Work experience } \\
\hline $3-5$ years & 6 & 14.29 \\
\hline $6-10$ years & 15 & 35.71 \\
\hline $11-15$ years & 18 & 42.86 \\
\hline More than 15 years & 3 & 7.14 \\
\hline \multicolumn{3}{|l|}{ Occupation } \\
\hline Private sector & 29 & 69.05 \\
\hline Public sector & 8 & 19.05 \\
\hline Experts from consultancy & 5 & 11.90 \\
\hline \multicolumn{3}{|l|}{ Position } \\
\hline Administrative staff & 34 & 80.95 \\
\hline Basic staff & 8 & 19.05 \\
\hline \multicolumn{3}{|l|}{ Case } \\
\hline Lianjiang Tangshan Water Plant & 2 & 4.76 \\
\hline Shandong Zhonghua Project & 3 & 7.14 \\
\hline $\begin{array}{c}\text { Tianjin Shuanggang Waste Incineration } \\
\text { Plant }\end{array}$ & 2 & 4.76 \\
\hline $\begin{array}{l}\text { Western Qinhuangdao Waste } \\
\text { Incineration Plant }\end{array}$ & 3 & 7.14 \\
\hline Wuxi Xidong Waste Incineration Plant & 3 & 7.14 \\
\hline $\begin{array}{c}\text { Beijing Liulitun Waste Incineration } \\
\text { Plant }\end{array}$ & 5 & 11.90 \\
\hline $\begin{array}{c}\text { Kunming Wuhua Waste Incineration } \\
\text { Plant }\end{array}$ & 2 & 4.76 \\
\hline $\begin{array}{c}\text { Qingdao Veolia Sewage Treatment } \\
\text { Project }\end{array}$ & 4 & 9.52 \\
\hline $\begin{array}{c}\text { Changzhou Hengshanqiao Sewage } \\
\text { Treatment Project }\end{array}$ & 2 & 4.76 \\
\hline $\begin{array}{c}\text { Changchun Huijin Sewage Treatment } \\
\text { Project }\end{array}$ & 3 & 7.14 \\
\hline $\begin{array}{c}\text { Wuhan Tangxuhu Sewage Treatment } \\
\text { Project }\end{array}$ & 3 & 7.14 \\
\hline Shenyang No. 9 Water Plant & 3 & 7.14 \\
\hline Hancheng Sewage Treatment Project & 2 & 4.76 \\
\hline Luoyang Sewage Treatment Project & 3 & 7.14 \\
\hline Muping Waste Incineration Plant & 2 & 4.76 \\
\hline
\end{tabular}

same outcome and conditions are transformed into 6 configurations. It is generated with the software Tosmana 1.6.0.0.

While 15 cases are shown in the study, the truth table reveals that limited diversity exists, not all logically possible combinations among these four conditions could be empirically observed. Moreover, it also can be presented visually by Venn diagram (Figure 7).

6.2. Analysis on csQCA Solution Formula. The solution formula is consisted in outcome and certain conditions which are linked with Boolean operators. There are three basic Boolean operators: logical AND (*), logical OR (+), and logical NOT (where lowercase letter was used to replace uppercase letter). This analysis reveals two sufficient primitive expressions that can be expressed in Boolean terms (Figure 8).
The solution formula above shows two combinations leading to severe extent of credit default. The conditions of political performance (PP) AND fiscal illusion (FI) are both existed OR the condition of political performance (pp) is absent AND the conditions of subjective willingness (SW) AND objective limitation (OL) are both existed which will result in severe extent of credit default.

6.3. Measures of Fit: Consistency and Coverage. Consistency and coverage are two critical parameters for assessing the fit of QCA results [143].

In csQCA method, the relation of consistency reveals the proportion of cases with given condition or combination of causes which leads to the outcome [144]. Thus, as shown in Table 8, all eight cases with PP * FI (rows 6-9) display 1 as the binary value of outcome; hence, the consistency of $\mathrm{PP} * \mathrm{FI}$ is $8 / 8=100 \%$. Similarly, the consistency of $\mathrm{pp} * \mathrm{SW} * \mathrm{OL}$ is $2 / 2=100 \%$. These results are presented in Table 9.

The other parameter is coverage which could be divided into raw coverage and unique coverage. The higher the coverage for the given conditions, the more the cases presenting certain outcome covered. Table 8 shows that ten cases display 1 as the outcome and the solution formula $\mathrm{PP} * \mathrm{FI}+\mathrm{pp} * \mathrm{SW} * \mathrm{OL}$ covers all of them. Thus, the overall of all sufficient conjunction combined is $10 / 10=1.00$. The solution formula $\mathrm{PP} * \mathrm{FI}$ alone covers eight of ten cases and $\mathrm{pp} * \mathrm{SW} * \mathrm{OL}$ covers two of ten cases, therefore, the raw coverage for $\mathrm{PP} * \mathrm{FI}$ is $8 / 10=0.80$, similarly, the raw coverage for $\mathrm{pp} * \mathrm{SW} * \mathrm{OL}$ is $2 / 10=0.20$. In addition, subtraction is used to calculate the unique coverage for each combination. The unique coverage of $\mathrm{PP} * \mathrm{FI}$ is calculated by subtracting the raw coverage of $\mathrm{pp} * \mathrm{SW} * \mathrm{OL}(20 \%)$ from solution formula $(100 \%)$. Thus, it is $1-0.2=0.80$. Similarly, the unique coverage of $\mathrm{pp} * \mathrm{SW} * \mathrm{OL}$ is $20 \%$. All of the results calculated above are summarized in Table 10.

\section{Research Findings}

7.1. Combination Analysis. Based on the conclusion found by Ragin, the consistency score should be as closer to 1 as possible.

The results of consistency for each combination which is shown in Figure 7 clearly illustrate PP $*$ FI OR pp $* \mathrm{SW} * \mathrm{OL}$ is sufficient to severe extent of credit default. As only two combinations were depicted in the manuscript, the raw consistency and unique consistency are equal for each combination. The research findings are analysed as follows.

7.1.1. $P P * F I$. For this approach, the raw coverage is 0.80 which shows that it is $80 \%$ possibility for LPSs with PP $*$ FI to make a severe extent of credit default in Government-Pay PPP projects.

This result could be well accepted corresponding to the reality in China. Most of the logics under PP $*$ FI are emerged in the preimplemention period, which could be generalized into Adverse Selection. In this time, LPSs officials are often under intense pressure to attract more 
TABLe 5: Results of each case under each logic.

\begin{tabular}{|c|c|c|c|c|c|c|c|c|c|c|c|c|}
\hline \multirow[t]{2}{*}{ Numbers } & \multirow[t]{2}{*}{ Number of respondents } & \multicolumn{3}{|c|}{$\begin{array}{l}\text { Political performance } \\
\text { (PP) }\end{array}$} & \multicolumn{2}{|c|}{$\begin{array}{c}\text { Fiscal } \\
\text { illusion (FI) }\end{array}$} & \multicolumn{3}{|c|}{$\begin{array}{l}\text { Subjective willingness } \\
\text { (SW) }\end{array}$} & \multicolumn{3}{|c|}{$\begin{array}{l}\text { Objective limitation } \\
(\mathrm{OL})\end{array}$} \\
\hline & & M1 & M2 & M3 & M4 & M5 & M6 & M7 & M8 & M9 & M10 & M11 \\
\hline Case 1 & 2 & 3.50 & 2.00 & 2.00 & 4.00 & 2.50 & 3.00 & 2.00 & 2.00 & 4.50 & 4.00 & 2.50 \\
\hline Case 2 & 3 & 1.00 & 2.33 & 4.00 & 2.66 & 1.67 & 1.67 & 3.67 & 2.33 & 2.00 & 2.33 & 3.67 \\
\hline Case 3 & 2 & 1.50 & 1.50 & 3.00 & 3.50 & 3.50 & 2.50 & 1.00 & 2.50 & 2.00 & 2.00 & 2.00 \\
\hline Case 4 & 3 & 2.67 & 2.00 & 3.67 & 1.67 & 1.33 & 2.67 & 2.00 & 2.33 & 4.00 & 2.67 & 2.33 \\
\hline Case 5 & 3 & 2.00 & 4.00 & 4.33 & 2.00 & 1.67 & 1.67 & 2.00 & 2.00 & 3.00 & 2.67 & 2.33 \\
\hline Case 6 & 5 & 3.20 & 2.20 & 4.20 & 2.00 & 2.00 & 2.00 & 2.00 & 2.20 & 2.00 & 2.20 & 3.00 \\
\hline Case 7 & 2 & 3.00 & 1.50 & 1.00 & 3.00 & 3.50 & 2.50 & 3.00 & 2.00 & 2.50 & 1.50 & 1.00 \\
\hline Case 8 & 4 & 3.50 & 2.50 & 2.50 & 4.00 & 3.50 & 2.00 & 2.00 & 2.00 & 2.00 & 2.50 & 3.00 \\
\hline Case 9 & 2 & 2.00 & 2.50 & 4.00 & 2.50 & 2.00 & 2.50 & 3.50 & 2.00 & 2.00 & 1.00 & 1.50 \\
\hline Case 10 & 3 & 4.00 & 1.67 & 1.67 & 3.00 & 3.33 & 2.67 & 3.33 & 3.67 & 2.67 & 2.00 & 2.33 \\
\hline Case 11 & 3 & 2.00 & 2.00 & 2.33 & 2.33 & 1.67 & 2.00 & 3.00 & 2.33 & 3.33 & 2.33 & 2.00 \\
\hline Case 12 & 3 & 2.67 & 4.00 & 2.67 & 3.00 & 3.00 & 2.67 & 4.00 & 2.00 & 2.33 & 2.33 & 3.00 \\
\hline Case 13 & 2 & 4.00 & 2.00 & 2.00 & 3.50 & 2.50 & 2.00 & 3.00 & 3.50 & 4.00 & 2.50 & 2.00 \\
\hline Case 14 & 3 & 3.00 & 2.33 & 2.00 & 4.33 & 2.33 & 2.67 & 2.00 & 3.00 & 3.33 & 2.67 & 2.67 \\
\hline Case 15 & 2 & 2.50 & 2.50 & 2.00 & 3.00 & 3.50 & 2.50 & 2.50 & 4.00 & 3.50 & 2.50 & 2.50 \\
\hline
\end{tabular}

TABLE 6: Results of each case under each logic.

\begin{tabular}{|c|c|c|c|c|c|c|c|c|c|c|c|}
\hline \multirow[t]{2}{*}{ Number } & \multicolumn{3}{|c|}{$\begin{array}{c}\text { Political } \\
\text { performance (PP) }\end{array}$} & \multicolumn{2}{|c|}{$\begin{array}{c}\text { Fiscal } \\
\text { illusion (FI) }\end{array}$} & \multicolumn{3}{|c|}{$\begin{array}{c}\text { Subjective } \\
\text { willingness (SW) }\end{array}$} & \multicolumn{3}{|c|}{ Objective limitation (OL) } \\
\hline & M1 & M2 & M3 & M4 & M5 & M6 & M7 & M8 & M9 & M10 & M11 \\
\hline Case 1 & $\sqrt{ }$ & & & $\sqrt{ }$ & & $\sqrt{ }$ & & & $\sqrt{ }$ & $\sqrt{ }$ & \\
\hline Case 2 & & & $\sqrt{ }$ & & & & $\sqrt{ }$ & & & & $\sqrt{ }$ \\
\hline Case 3 & & & $\sqrt{ }$ & $\sqrt{ }$ & $\sqrt{ }$ & & & & & & \\
\hline Case 4 & & & $\sqrt{ }$ & & & & & & $\sqrt{ }$ & & \\
\hline Case 5 & & $\sqrt{ }$ & $\sqrt{ }$ & & & & & & $\sqrt{ }$ & & \\
\hline Case 6 & $\sqrt{ }$ & & $\sqrt{ }$ & & & & & & & & $\sqrt{ }$ \\
\hline Case 7 & $\sqrt{ }$ & & & $\sqrt{ }$ & $\sqrt{ }$ & & $\sqrt{ }$ & & & & \\
\hline Case 8 & $\sqrt{ }$ & & & $\sqrt{ }$ & $\sqrt{ }$ & & & & & & $\sqrt{ }$ \\
\hline Case 9 & & & $\sqrt{ }$ & & & & $\sqrt{ }$ & & & & \\
\hline Case 10 & $\sqrt{ }$ & & & $\sqrt{ }$ & $\sqrt{ }$ & & $\sqrt{ }$ & $\sqrt{ }$ & & & \\
\hline Case 11 & & & & & & & $\sqrt{ }$ & & $\sqrt{ }$ & & \\
\hline Case 12 & & $\sqrt{ }$ & & $\sqrt{ }$ & $\sqrt{ }$ & & $\sqrt{ }$ & & & & $\sqrt{ }$ \\
\hline Case 13 & $\sqrt{ }$ & & & $\sqrt{ }$ & & & $\sqrt{ }$ & $\sqrt{ }$ & $\sqrt{ }$ & & \\
\hline Case 14 & $\sqrt{ }$ & & & $\sqrt{ }$ & & & & $\sqrt{ }$ & $\sqrt{ }$ & & \\
\hline Case 15 & & & & $\sqrt{ }$ & $\sqrt{ }$ & & & $\sqrt{ }$ & $\sqrt{ }$ & & \\
\hline
\end{tabular}

TABle 7: Data matrix of each condition and damaged level.

\begin{tabular}{lccccc}
\hline Projects & PP & FI & SW & OL & Outcome (levels of credit default) \\
\hline Case 1 & 1 & 1 & 1 & 1 & 1 \\
Case 2 & 1 & 0 & 1 & 1 & 0 \\
Case 3 & 1 & 1 & 0 & 0 & 1 \\
Case 4 & 1 & 0 & 0 & 1 & 0 \\
Case 5 & 1 & 0 & 0 & 1 & 0 \\
Case 6 & 1 & 0 & 0 & 1 & 0 \\
Case 7 & 1 & 1 & 1 & 0 & 1 \\
Case 8 & 1 & 1 & 0 & 1 & 1 \\
Case 9 & 1 & 0 & 1 & 0 & 0 \\
Case 10 & 1 & 1 & 1 & 0 & 1 \\
Case 11 & 0 & 0 & 1 & 1 & 1 \\
Case 12 & 1 & 1 & 1 & 1 & 1 \\
Case 13 & 1 & 1 & 1 & 1 & 1 \\
Case 14 & 1 & 1 & 1 & 1 & 1 \\
Case 15 & 0 & 1 & 1 & 1 & \\
\hline
\end{tabular}

TABLE 8: Truth table of conditions and outcome.

\begin{tabular}{lccccc}
\hline Case number & PP & FI & SW & OL & Outcome \\
\hline 11 & 0 & 0 & 1 & 1 & 1 \\
15 & 0 & 1 & 1 & 1 & 1 \\
$4,5,6$ & 1 & 0 & 0 & 1 & 0 \\
9 & 1 & 0 & 1 & 0 & 0 \\
2 & 1 & 0 & 1 & 1 & 0 \\
3 & 1 & 1 & 0 & 0 & 1 \\
8 & 1 & 1 & 0 & 1 & 1 \\
7,10 & 1 & 1 & 1 & 0 & 1 \\
$1,12,13,14$ & 1 & 1 & 1 & 1 & 1 \\
\hline
\end{tabular}

investments by PPP mode during their term of office. Thus, logics like unrealistic guarantee and corruption are revealed in certain cases. When officials or policies are changed, LPSs 


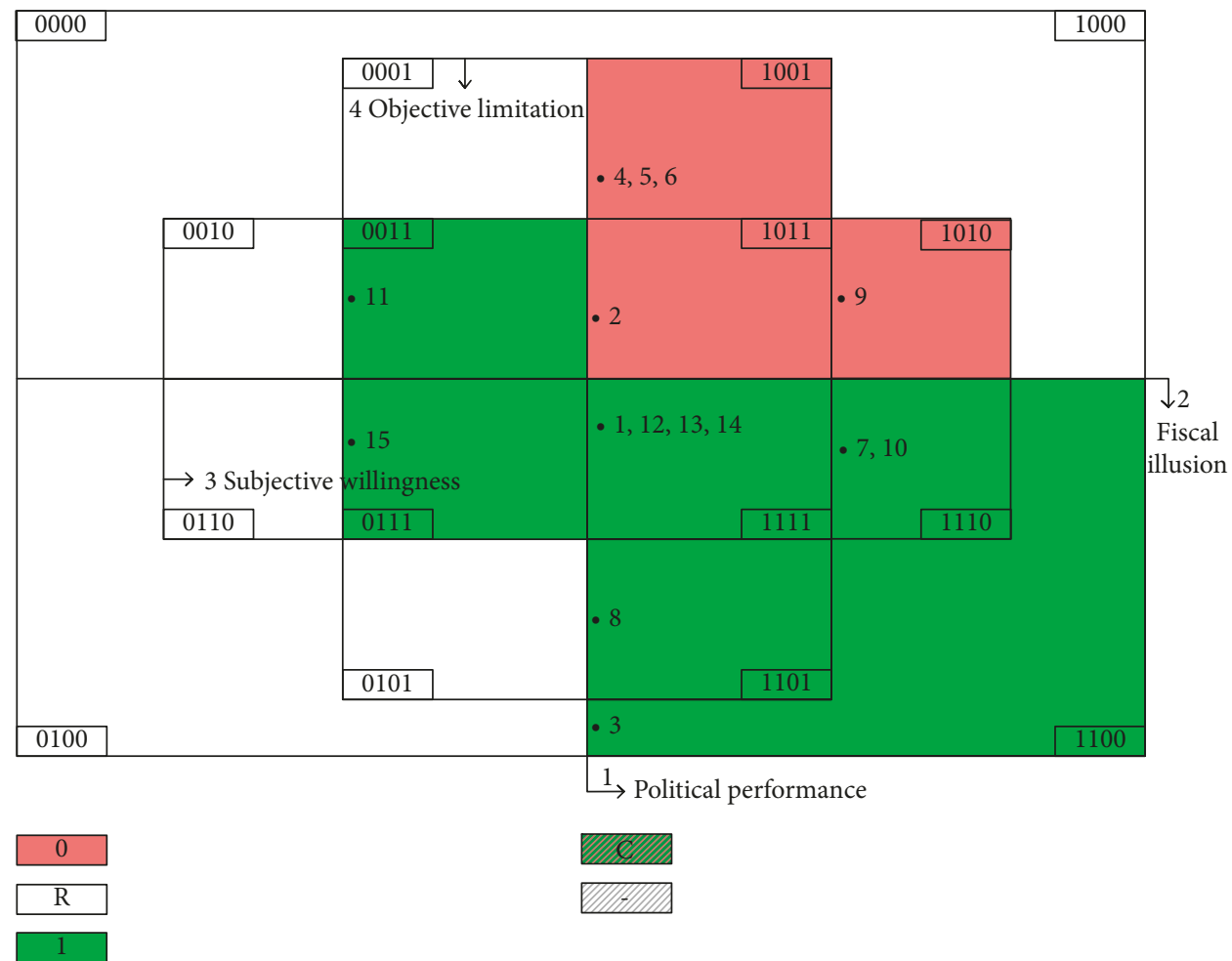

FIgURE 7: Credit default solution formula.

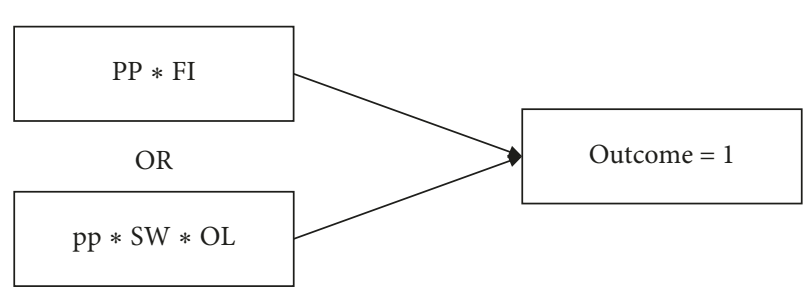

FIgURE 8: Credit default solution formula.

are tending to take the straightforward measurements (involving government buyback, social capital withdrawn investment, and government halt) to regain the projects in short time. Comparing to other behaviours of credit default, government buyback and halting the project directly are most usual; additionally, LPSs could also be tempted to make SOE take over the control power belonging to social capitals in Government-Pay PPP projects.

The unique regime and special financial system should never be neglected. As Case 13-Case 15 revealed, when LPSs disputed several orders to emphasize the risk of government debts in 2018, some local authorities regarded all kinds of Government-Pay PPP projects as government obligations and halted them promptly to make response. Once the logics under $\mathrm{PP} * \mathrm{FI}$ are existed, the projects are highly possible to be early terminated and hard to continue.

7.1.2. $p p * S W * O L$. For this approach, the raw coverage is 0.20 which shows that it is $20 \%$ possibility for LPSs with $\mathrm{pp} * \mathrm{SW} * \mathrm{OL}$ to make a severe extent of credit default in Government-Pay PPP projects. The logics under $\mathrm{pp} * \mathrm{SW} * \mathrm{OL}$ are used to occur in the implementing period or the postimplementing period; they could be generalized into Moral Hazard.

When PPP projects get into construction or operation stage without suffering from the credit default of PP, there will be new risks to face: $\mathrm{SW} * \mathrm{OL}$. The path dependence towards traditional mode leads to the abuse of power without effective supervision. As Case 10 and Case 12 depicted, in operation stage, LPSs may start to realize that they are hard to fulfil the commitments they ever promised. In consideration of the insufficient expertise in renegotiation for LPSs, the cooperation between social capitals and public authorities is going to be collapsed by government buyback or cut off. Only few private sectors with strong antirisk ability could make adjustment for renegotiation with LPSs to avoid a breach. In addition, transaction costs in signing, performance, revising, and information searching of contracts may cause more loss than termination. From this perspective, halting the projects is not always irrational.

While the raw coverage is different between two combinations, the consistency for each one is $100 \%$ which is obviously to reveal that $\mathrm{PP} * \mathrm{FI}$ and $\mathrm{pp} * \mathrm{SW} * \mathrm{OL}$ are both completely sufficient for leading severe extent of credit default.

7.2. Condition Analysis. The consistency and raw coverage for each condition alone are presented in Table 11.

Apparently, FI is the most critical among four conditions to lead severe extent of credit default with the highest score of consistency and coverage. Especially, the consistency of FI is $100 \%$ which means it is completely sufficient to cause a grave consequence. To be more specific, each case shown in Table 8 with the logics of M4 (poor cognition) and M5 
TABLE 9: Sufficient conditions with severe extent of credit default as the variable outcome.

\begin{tabular}{|c|c|c|c|}
\hline $\begin{array}{l}\text { (a) Cross-tab showing "PP } * \text { FI" as a sufficient } \\
\text { condition for credit default }\end{array}$ & Without "PP * FI" & With "PP * FI" & \\
\hline Outcome is 0 & 5 & 0 & 5 \\
\hline \multirow{2}{*}{ Outcome is 1} & 2 & 8 & 10 \\
\hline & 7 & 8 & $N=15$ \\
\hline $\begin{array}{l}\text { (b) Cross-tab showing "pp } * \mathrm{SW} * \mathrm{OL} \text { " as a sufficient } \\
\text { condition for credit default }\end{array}$ & Without "pp $* \mathrm{SW} * \mathrm{OL}$ " & With “pp $* \mathrm{SW} * \mathrm{OL}$ ” & \\
\hline Outcome is 0 & 5 & 0 & 5 \\
\hline \multirow[t]{2}{*}{ Outcome is 1} & 8 & 2 & 10 \\
\hline & 13 & 2 & $N=15$ \\
\hline $\begin{array}{l}\text { (c) Cross-tab showing "PP } * \mathrm{FI} \text { " or "pp } * \mathrm{SW} * \mathrm{OL} \text { " as } \\
\text { a sufficient condition for credit default }\end{array}$ & $\begin{array}{l}\text { Without "PP } * \text { FI" or } \\
\text { "pp } * \mathrm{SW} * \mathrm{OL} \text { " }\end{array}$ & $\begin{array}{l}\text { With "PP } * \text { FI" or } \\
\text { "pp } * \mathrm{SW} * \mathrm{OL} \text { " }\end{array}$ & \\
\hline Outcome is 0 & 5 & 110 & 5 \\
\hline \multirow[t]{2}{*}{ Outcome is 1} & 0 & 10 & 10 \\
\hline & 5 & 10 & $N=15$ \\
\hline
\end{tabular}

TABLE 10: Results of coverage and consistency analysis.

\begin{tabular}{lccc}
\hline Casual configuration & $\begin{array}{c}\text { Raw } \\
\text { coverage }\end{array}$ & $\begin{array}{c}\text { Unique } \\
\text { coverage }\end{array}$ & Consistency \\
\hline $\mathrm{PP} * \mathrm{FI}$ & 0.80 & 0.80 & 1.00 \\
$\mathrm{pp} * \mathrm{SW} * \mathrm{OL}$ & 0.20 & 0.20 & 1.00 \\
Solution coverage: 1.00 & & & \\
Solution consistency: 1.00 & & & \\
\hline
\end{tabular}

(unreasonable guarantee) is doomed to make a bad ending. The result illustrates that LPSs kept an unclear cognition on the meaning, purpose, and process of Government-Pay PPP mode. Some authorities always believed that PPP projects could be implemented with lower costs even noncost. Thus, irrational promises were made to tout for investment from social capitals which is totally impossible to execute. Hence, $\mathrm{H} 2$ could be accepted and it will lead a dire ending more than credit default.

The consistency for PP, SW, and OL alone is not $100 \%$, and there is no dominant connection for each one of them to cause severe extent of credit default like FI does. However, the consistency for $\mathrm{PP} * \mathrm{FI}$ or $\mathrm{pp} * \mathrm{SW} * \mathrm{OL}$ is $100 \%$, and each one of the three conditions does contribute to credit default in different levels. Thus, H1, H3, and H4 should be accepted. More quantitative analysis could be generated to figure out the precise relationship between certain condition and outcome in the future.

\section{Discussion}

After the data analysis, we contacted the respondents in our research and conducted follow-up interviews to test the validity of the identified approaches. Among the 42 interviewees, 37 took part in the follow-up interviews and confirmed the findings of this study. However, several findings must be discussed.

In terms of "PP $*$ FI," two points should be emphasized. First, considering China's unique political system, the combination between the logics of political pressure and unreasonable guarantee from certain backgrounds of the times contributes critically to the emergence of "PP * FI." For example, Shenzhen Shajiao B Power Plant, China's first PPP project, was an attempt to introduce foreign capital and
TABLE 11: Results of raw coverage and consistency for each condition.

\begin{tabular}{lcc}
\hline Casual configuration & Raw coverage & Consistency \\
\hline PP & 0.80 & 0.62 \\
FI & 0.90 & 1.00 \\
SW & 0.80 & 0.80 \\
OL & 0.70 & 0.64 \\
\hline
\end{tabular}

explore marketization during the special time of reform and opening. In Case 8, Qingdao was selected as the host city of the water-related events of the 2008 Olympic Games. Qingdao had to raise its urban environmental conditions to a higher standard before the Olympic Games. Thus, a partnership was established with the water giant France Veolia Group in the PPP Sewage Treatment Project with LPSs. Local authorities lacked time to undertake a feasibility research, and therefore, several unrealistic guarantees were made, leading to a complicated and inconsistent negotiation process. As one interviewee from LPSs in Case 8 responded:

"Exactly. We lacked experience in 2003. The sewage treatment fee was 1 yuan/t in Qingdao, which was higher than in most cities in China. However, it still failed to meet the contracted level of return. Raising sewage treatment fee in a short term must lead to public opposition, and we realized the contracted level is unfair."

The construction of the Beijing Liulitun Waste Incineration Plant in Case 6 was also under the background of the Olympic Games. Local governments favored the professional competence of social capitals to improve the environment of Beijing as soon as possible, but eventually led to strong public opposition. Most of the logics under "PP * FI" have a typical effect on the intention and actual behaviour in the decision-making process of LPSs. Once "PP * FI" emerged, it was nearly impossible to reconcile in negotiation.

Second, the consistency of PP and FI alone is $8 / 13=0.62$ and 1.00, respectively, which indicates that PP may not lead to the severe extent of the credit default with $38 \%$ possibilities independently. It could be examined in the specific logic. On the one hand, public opposition is a certain logic under the condition of PP and is also a common problem that emerged in ecological construction as shown in Cases 
2-6 and in Case 9. The "not in my backyard" movement often happens in sewage treatment and waste incineration projects. Information gaps and professional barriers exist between the technical indicator and the public's traditional consciousness. The public is highly susceptible to the media, which aggravates the dispute, consequently leading to a mass incident. As explained by one of the local officials in Case 6:

"Actually we could not find such a large space in Beijing to build a waste treatment plant and all citizens would protest against it if this project is located in their community..."

Under this circumstance, relocation and temporary cessation could be deemed as effective approaches for LPSs to avoid the severe extent of credit default as shown in Cases 4-6 and Case 9. On the other hand, all cases with FI could be identified with the existence of poor cognition, which in turn will cause the credit default of LPSs as shown in Cases 1, 3, 7, $8,10,12,13,14$, and 15 . In China, CPSs have a relatively clear value orientation in this round of PPP promotion. However, misunderstanding of the Government-Pay PPP mode by LPSs occurs because of the multilayer principal-agent structure in the bureaucracy and the cognitive bias of public officials. The extreme cognition that "PPP is much cheaper or even free" generated many unsuitable projects for implementation. As the evidence from Case 13 revealed, the project was ejected from the Demonstration Projects Database of the China PPP Center because of the perfunctory procedure of $\mathrm{Vfm}$.

As for "pp * SW * OL," an interesting difference must be emphasized. The consistencies of "pp $* \mathrm{SW} * \mathrm{OL}$," "FI $* \mathrm{SW} * \mathrm{OL}$," and "SW $* \mathrm{OL}$ " are $2 / 2=1.00,5 / 5=1.00$, and $6 / 7=0.86$, respectively. Table 11 reveals that FI completely embraces sufficiency to cause a grave consequence of the Government-Pay PPP project. Thus, selected cases with $\mathrm{FI}$ in "SW $* \mathrm{OL}$ " reveal a severe extent of the credit default of LPSs, which make up 5/7 $=0.71$ of all cases with "SW $*$ OL." However, the different results from Cases 2, 15, and 11 confirmed the sufficiency of the absence of PP. Thus, "pp $* \mathrm{SW} * \mathrm{OL}$ " was identified as a credit default solution formula of LPSs in Government-Pay PPP projects reaching its severe extent by utilizing the Tosmana 1.6.0.0 software. The response to the policy changes of LPSs must be highlighted, because cases with this logic are doomed to fail. In Case 10, LPSs of Changchun signed a PPP contract with the private sector and made certain unreasonable guarantees on the level of revenue. However, CPSs approved the banning of PPP projects with fixed return in 2002 [145]. The local governments had to respond, and they did by voiding the agreement and refusing to pay for SPV, which led to their being charged in 2003. Policy change could damage the sustainability of PPP projects directly, especially those with the Government-Pay mechanism.

\section{Conclusion}

This research analyses the connection between certain critical conditions and credit default of LPSs in Chinese GovernmentPay PPP projects based on the cases selected in the field of ecological construction. By literature review, four conditions are determined as variables: political performance, fiscal illusion, subjective willingness, and objective limitation. Thus, four hypotheses are made in accordance with each condition. Additionally, we categorize eleven logics under four conditions for more accurate assignment in csQCA method. The results of csQCA not only illustrate the hypotheses that could be accepted that political performance, fiscal illusion, subjective willingness, and objective limitation contribute to opportunism of LPSs in Government-Pay PPP projects but also explore the sufficiency of each condition to severe extent of credit default.

Moreover, several findings are shown as follows: (1) the configurations of $\mathrm{PP} * \mathrm{FI}$ and $\mathrm{pp} * \mathrm{SW} * \mathrm{OL}$ are both completely sufficient to severe extent of credit default. We may simplify that the opportunistic logics leading to the termination of Government-Pay PPP projects in preimplementation link are attributed to $\mathrm{PP} * \mathrm{FI}$, and similarly, others in the periods of implementation or transfer could be attributed to $\mathrm{pp} * \mathrm{SW} * \mathrm{OL} ;(2)$ Government-Pay PPP projects with the potential risks cited in fiscal illusion are doomed to cause a serious breach because of the poor cognition on PPP mode or unrealistic promises made by LPSs; (3) while the research findings reveal that political performance, subjective willingness, and objective limitation contain incomplete sufficiency to severe extent of credit default based on the selected cases, attention should also be paid to the specific logics like political pressure, repudiation of payment, abuse of power, and poor decision-making procedure. Further studies could be conducted in these aspects.

The values of this manuscript are not confined in the following two aspects. Theoretically, it enriches the research of credit default from LPSs in Government-Pay PPP projects, but also analyses the connections between certain conditions and serious breach. From practical perspective, the research findings could be reference for both public authorities and social capitals. On the one hand, CPSs can issue more pertinent regulations to restrain the opportunistic behaviours of stakeholders in PPP projects and supervise the excise of power by LPSs based on our study. On the other hand, social capitals may forecast the potential risks and make allocation structure in more rational way according to the findings.

However, there are still some limitations considering the objectives in our research. All cases selected in this manuscript are from the field of ecological construction. Though Government-Pay mechanism is widely used in ecological construction and environment protection, the result based on these cases may not fully reveal the connection between certain condition and credit default in all Government-Pay PPP projects. Moreover, csQCA has limitation in Quantitative analysis, and further details on the impact mechanism of each condition should be explored by other methods. In the future, the deeper analysis will be facilitated to find more valuable cases and critical conditions for normalizing the behaviours of not only public authorities but also all participators in Chinese Government-Pay PPP projects.

\section{Data Availability}

The data used to support the findings of this study are available from the corresponding author upon request. 


\section{Disclosure}

The founding sponsors had no role in the design of the study; the collection, analyses, and interpretation of data; the writing of the manuscript; and the decision to publish the results.

\section{Conflicts of Interest}

The authors declare that they have no conflicts of interest.

\section{Acknowledgments}

This research received funding from Major Financial Application Projects of Shandong Province, China (CJ-201704), and Social Science Planning Project of Shandong Province, China (16CGLJ22).

\section{Supplementary Materials}

The information of questionnaire is shown in Appendix 1: variables and survey items are revealed in column 1, and scoring of Likert scale is provided in row 2 . Based on the description, the supplementary materials could be easier to understand. (Supplementary Materials)

\section{References}

[1] J. Song, Y. Hu, and Z. Feng, "Factors influencing early termination of PPP projects in China," Journal of Management in Engineering, vol. 34, no. 1, article 05017008, 2017.

[2] S. Zhang, Y. Gao, Z. Feng, and W. Sun, "PPP application in infrastructure development in China: institutional analysis and implications," International Journal of Project Management, vol. 33, no. 3, pp. 497-509, 2015.

[3] X. Zhang, "Critical success factors for public-private partnerships in infrastructure development," Journal of Construction Engineering and Management, vol. 131, no. 1, pp. 3-14, 2005.

[4] J.-F. Yuan, M. J. Skibniewski, Q. Li, and J. Shan, “The driving factors of China's public-private partnership projects in metropolitian transportation systems: public sector's viewpoint," Journal of Civil Engineering and Management, vol. 16, no. 1, pp. 5-18, 2010.

[5] Z. Cheng, Y. Ke, J. Lin, Z. Yang, and J. Cai, "Spatio-temporal dynamics of public private partnership projects in China," International Journal of Project Management, vol. 34, no. 7, pp. 1242-1251, 2016.

[6] A. Erridge and J. Greer, "Partnerships and public procurement: building social capital through supply relations," Public Administration, vol. 80, no. 3, pp. 503-522, 2010.

[7] L.-Y. Shen, A. Platten, and X. P. Deng, "Role of public private partnerships to manage risks in public sector projects in Hong Kong," International Journal of Project Management, vol. 24, no. 7, pp. 587-594, 2006.

[8] S. Zhang, A. P. C. Chan, Y. Feng, H. Duan, and Y. Ke, "Critical review on PPP research-a search from the Chinese and international journals," International Journal of Project Management, vol. 34, no. 4, pp. 597-612, 2016.

[9] A. B. S. Lecturer, Mapping of the PPP's Processes and Concepts, John Wiley \& Sons, Hoboken, NJ, USA, 2013.

[10] M. Regan, J. Smith, and P. E. D. Love, "Impact of the capital market collapse on public-private partnership infrastructure projects," Journal of Construction Engineering and Management, vol. 137, no. 1, pp. 6-16, 2011.

[11] P. Sun and C. Ren, "Research on PPP mode in ecological governance in China," Open Journal of Social Sciences, vol. 5, no. 6, pp. 175-187, 2017.

[12] T. Sachs, R. Tiong, and S. Qing Wang, "Analysis of political risks and opportunities in public private partnerships (PPP) in China and selected Asian countries," Chinese Management Studies, vol. 1, no. 2, pp. 126-148, 2007.

[13] C. P. Center, Circular of the Ministry of Finance on Issuing the Operational Guidelines for Public-Private Partnership Mode (for Trial Implementation), 2014.

[14] C. Y. Chang and S. Chen, "An analysis of transitional publicprivate partnerships model in China: contracting with little recourse to contracts," Journal of Construction Engineering \& Management, vol. 142, no. 10, 2016.

[15] C. P. Center, Quarterly Report on the Project Database of the National PPP Integrated Information Platform 2nd Quarter of 2018, 2018.

[16] J. Loxley, "Are public-private partnerships (PPPs) the answer to Africa's infrastructure needs?," Review of African Political Economy, vol. 40, no. 137, pp. 485-495, 2013.

[17] C. Y. Chang and H. Y. Chou, "Transaction-cost approach to the comparative analysis of user-pay and government-pay public-private partnership systems," Journal of Construction Engineering \& Management, vol. 140, no. 9, article 04014039, 2013.

[18] S. Q. Wang, R. L. K. Tiong, S. K. Ting, and D. Ashley, "Evaluation and management of political risks in China's BOT projects," Journal of Construction Engineering and Management, vol. 126, no. 3, pp. 242-250, 2000.

[19] X. Zhou, "The institutional logic of collusion among local governments in China," Modern China, vol. 36, no. 1, pp. 47-78, 2010.

[20] A. M. Dudas, "The use of community opinion surveys in local government strategic decision making (electronic resource)," Journal of the Society of Materials Science Japan, vol. 55, no. 8, pp. 777-784, 2005.

[21] B. Ryan, "How can the corporate sector concepts of "reputation" and "trust" be used by local government? A study to establish a model of reputation management for local government," Social Science Electronic Publishing, vol. 8, no. 2007, pp. 37-75, 2007.

[22] Y. Zhang, J. Gu, M. Shan et al., 'Investigating private sectors' behavioral intention to participate in PPP projects: an empirical examination based on the theory of planned behavior," Sustainability, vol. 10, no. 8, p. 2692, 2018.

[23] E. Iossa and D. Martimort, "The simple microeconomics of public-private partnerships," Journal of Public Economic Theory, vol. 17, no. 1, pp. 4-48, 2015.

[24] C. P. Center Circular of the Ministry of Finance on Issuing the Guidelines for the Financial Affordability Assessment of the Public-Private Partnership Projects. http://www.cpppc. org/en/Guidelines/4049.jhtml.

[25] D. Grimsey and M. K. Lewis, "Evaluating the risks of public private partnerships for infrastructure projects," International Journal of Project Management, vol. 20, no. 2, pp. 107-118, 2002.

[26] J. E. Stiglitz and A. Weiss, "Credit rationing in markets with imperfect information," American Economic Review, vol. 71, no. 3, pp. 393-410, 1981.

[27] D. C. North, Institutions, Institucional Change and Economic Performance, Cambridge University Press, Cambridge, UK, 1990. 
[28] N. S. Mansor and K. A. Rashid, "Incomplete contract in private finance initiative (PFI) contracts: causes, implications and strategies," Procedia-Social and Behavioral Sciences, vol. 222, pp. 93-102, 2016.

[29] R. N. Fernandez, H. Saulo, A. Carraro, F. Tourrucôo, and R. Hillbrecht, "Public-private partnership contractual design: a computational model of the moral hazard with lotteries," Public Organization Review, vol. 18, no. 1, pp. 39-51, 2018.

[30] I. Hajjej, C. Hillairet, M. Mnif, and M. Pontier, "Optimal contract with moral hazard for public private partnerships," Stochastics-An International Journal of Probability \& Stochastic Processes, vol. 89, no. 6-7, pp. 1015-1038, 2017.

[31] X. Wu, Y. Peng, X. Liu, and J. Zhou, "Validity of generalized compensation contract for PPP project with consideration of private fair reference depending on concession profit," China Finance Review International, vol. 8, no. 1, pp. 43-68, 2018.

[32] P. Padma, Á. Rosa, and N. Antonio, "Antecedents and consequences of mutual trust in PPPs," Journal of Relationship Marketing, vol. 16, no. 3, pp. 163-178, 2018.

[33] J. Froud, "The private finance initiative," Accounting, Organizations and Society, vol. 28, no. 6, pp. 567-589, 2003.

[34] H. S. Robinson and J. Scott, "Service delivery and performance monitoring in PFI/PPP projects," Construction Management and Economics, vol. 27, no. 2, pp. 181-197, 2009.

[35] Y. Luo, "Contract, cooperation, and performance in international joint ventures," Strategic Management Journal, vol. 23, no. 10, pp. 903-919, 2002.

[36] A. A.-N. Abdallah, M. Darayseh, and E. Waples, "Incomplete contract, agency theory and ethical performance: a synthesis of the factors affecting owners' and contractors' performance in the bidding construction process," Journal of General Management, vol. 38, no. 4, pp. 39-56, 2013.

[37] R. E. Freeman and Philosophy Documentation Center, "The politics of stakeholder theory," Business Ethics Quarterly, vol. 4, no. 4, pp. 409-421, 1994.

[38] C. Freeman, "Networks of innovators: a synthesis of research issues," Research Policy, vol. 20, no. 5, pp. 499-514, 1991.

[39] T. R. Zenger, S. G. Lazzarini, and L. Poppo, "Informal and formal organization in new institutional economics," SSRN Electronic Journal, vol. 19, no. 1, pp. 277-305, 2001.

[40] O. Hart and J. Moore, "Contracts as reference points," Quarterly Journal of Economics, vol. 123, no. 1, pp. 1-48, 2008.

[41] C. Benítez-Ávila, A. Hartmann, G. Dewulf, and J. Henseler, "Interplay of relational and contractual governance in public-private partnerships: the mediating role of relational norms, trust and partners' contribution," International Journal of Project Management, vol. 36, no. 3, pp. 429-443, 2018.

[42] L. Yan, Z. Shi, M. Yan, and J. Deng, "Contractual governance and relational governance in public construction project: substitutes or complements?," Tumu Gongcheng Xuebao/ China Civil Engineering Journal, vol. 49, no. 11, pp. 115-128, 2016.

[43] V. Valero, "Government opportunism in public-private partnerships," Journal of Public Economic Theory, vol. 17, no. 1, pp. 111-135, 2015.

[44] E. Iossa and D. Martimort, "Corruption in PPPs, incentives and contract incompleteness," International Journal of Industrial Organization, vol. 44, pp. 85-100, 2016.

[45] A. Estache, J.-L. Guasch, A. Iimi, and L. Trujillo, "Multidimensionality and renegotiation: evidence from transport- sector public-private-partnership transactions in Latin America," Review of Industrial Organization, vol. 35, no. 1-2, pp. 41-71, 2009.

[46] E. Smith, T. Umans, and A. Thomasson, "Stages of PPP and principal-agent conflicts: the Swedish water and sewerage sector," Public Performance \& Management Review, vol. 41, no. 1, pp. 1-30, 2017.

[47] Y. Wang and J. Liu, "Evaluation of the excess revenue sharing ratio in PPP projects using principal-agent models," International Journal of Project Management, vol. 33, no. 6, pp. 1317-1324, 2015.

[48] X. Zhou, H. Lian, L. Ortolano, and Y. Ye, "A behavioral model of "muddling through" in the Chinese bureaucracy: the case of environmental protection," China Journal, vol. 70, no. 1, pp. 120-147, 2013.

[49] L.-Y. Zhang, "Chinese central-provincial fiscal relationships, budgetary decline and the impact of the 1994 fiscal reform: an evaluation," China Quarterly, vol. 157, pp. 115-141, 1999.

[50] B. Grewal, E. Cheng, and B. Rasmussen, "Local government debt in China: implications for reform," Public Finance \& Management, vol. 15, no. 4, pp. 358-377, 2015.

[51] R. Tao, F. Su, M. Liu, and G. Cao, "Land leasing and local public finance in China's regional development: evidence from prefecture-level cities," Urban Studies, vol. 47, no. 10, pp. 2217-2236, 2010.

[52] X. X. Zhu, C. O. Economics, and F. N. University, "The reform of financing methods in the context of new-type urbanization: from land finance to PPP," Journal of Fujian Commercial College, vol. 3, 2015.

[53] K. Li and D. Wu, "Hierarchical division, characteristics and practice of PPP model in China," Journal of Beijing Jiaotong University, vol. 16, 2017, in Chinese.

[54] G. A. Hodge, "The risky business of public-private partnerships," Australian Journal of Public Administration, vol. 63, no. 4, pp. 37-49, 2004.

[55] Z. J. Zhao, G. Su, and D. Li, "The rise of public-private partnerships in China," Journal of Chinese Governance, vol. 3, no. 2, pp. 158-176, 2018.

[56] P. J. May, S. Workman, and B. D. Jones, "Organizing attention: responses of the bureaucracy to agenda disruption," Journal of Public Administration Research \& Theory, vol. 18, no. 4, pp. 517-541, 2008.

[57] N. N. Liu, C. W.-H. Lo, X. Zhan, and W. Wang, "Campaignstyle enforcement and regulatory compliance," Public Administration Review, vol. 75, no. 1, pp. 85-95, 2015.

[58] N. Li and Q. Song, "Public-private partnership in developing China: evolution, institutionalization and risks," in The Emerald Handbook of Public-Private Partnerships in Developing and Emerging Economies: Perspectives on Public Policy, Entrepreneurship and Poverty, pp. 113-139, Emerald Publishing Limited, Bingley, UK, 2017.

[59] P. S. Yu, Z. Z. Chen, and J. Sun, "Innovative financing: an empirical study on public-private partnership securitisation in China," Australian Economic Papers, vol. 57, no. 3, 2018.

[60] Y. Xing, Y. Liu, and S. C. L. Cooper, "Local government as institutional entrepreneur: public-private collaborative partnerships in fostering regional entrepreneurship," British Journal of Management, vol. 29, no. 4, 2018.

[61] M. Edin, "State capacity and local agent control in China: CCP cadre management from a township perspective," China Quarterly, vol. 173, pp. 35-52, 2003.

[62] G. Tullock, The Politics of Bureaucracy, Longman, Harlow, UK, 1984. 
[63] V. Ostrom and E. Ostrom, "Public choice: a different approach to the study of public administration," Public Administration Review, vol. 31, no. 2, pp. 203-216, 1971.

[64] S. Biddulph, S. Cooney, and Y. Zhu, "Rule of law with Chinese characteristics: the role of campaigns in lawmaking," Law \& Policy, vol. 34, no. 4, pp. 373-401, 2012.

[65] A. Akintoye, C. Hardcastle, M. Beck, E. Chinyio, and D. Asenova, "Achieving best value in private finance initiative project procurement," Construction Management and Economics, vol. 21, no. 5, pp. 461-470, 2003.

[66] T. Y. Wang, "PPP's feelings and patterns," China Finance, no. 8 , pp. $40-42,2017$, in Chinese.

[67] G. Xiao, "Cold thinking of the PPP boom," China Economic Weekly, vol. 42, pp. 26-29, 2014, in Chinese.

[68] P. Pierson, "Increasing returns, path dependence, and the study of politics," American Political Science Review, vol. 94, no. 2, pp. 251-267, 2000.

[69] Y. Lu and T. Sun, "Local government financing platforms in China: a fortune or misfortune?," IMF Working Papers, vol. 13, no. 243, p. 1, 2014.

[70] S. Rogers, "Betting on the strong: local government resource allocation in China's poverty counties," Journal of Rural Studies, vol. 36, pp. 197-206, 2014.

[71] Y. Hu, Y. Yang, and P. Han, "Credit enhancement and bond rating," China Finance Review International, vol. 7, no. 1, pp. 114-130, 2017.

[72] G. Götz, "Sunk costs, windows of profit opportunities, and the dynamics of entry," International Journal of Industrial Organization, vol. 20, no. 10, pp. 1409-1436, 2002.

[73] R. Rai and V. Allada, "Modular product family design: agentbased pareto-optimization and quality loss function-based post-optimal analysis," International Journal of Production Research, vol. 41, no. 17, pp. 4075-4098, 2003.

[74] F. Su, R. Tao, L. Xi, and M. Li, "Local officials' incentives and China's economic growth: tournament thesis reexamined and alternative explanatory framework," China \& World Economy, vol. 20, no. 4, pp. 1-18, 2012.

[75] L. Zhou, "Problems in applying PPP in land development and suggestions for countermeasures," Chinese Lawyer, vol. 12, 2016, in Chinese.

[76] X. He, J. Chen, and X. Zhang, "Say no to "pseudo-PPP": game analysis of packaging commercial projects into PPP," Finance and Accounting Monthly, vol. 15, 2018, in Chinese.

[77] L. Zhang, "Promote the three major points of PPP: avoid deteriorating PPP, increase the enthusiasm of private capital, and accelerate PPP legislation," China Economic Weekly, vol. 9, 2016, in Chinese.

[78] A. R. Vining, A. E. Boardman, and F. Poschmann, "Publicprivate partnerships in the US and Canada: "there are no free lunches"1," Journal of Comparative Policy Analysis: Research and Practice, vol. 7, no. 3, pp. 199-220, 2005.

[79] S. H. Linder, "Coming to terms with the public-private partnership," American Behavioral Scientist, vol. 43, no. 1, pp. 35-51, 1999.

[80] G. M. Winch, "Institutional reform in British construction: partnering and private finance," Building Research \& Information, vol. 28, no. 2, pp. 141-155, 2000.

[81] L. Shan, M. J. Garvin, and R. Kumar, "Collar options to manage revenue risks in real toll public-private partnership transportation projects," Construction Management and Economics, vol. 28, no. 10, pp. 1057-1069, 2010.

[82] S. Q. Wang, R. L. K. Tiong, S. K. Ting, and D. Ashley, "Political risks: analysis of key contract clauses in China's
BOT project," Journal of Construction Engineering and Management, vol. 125, no. 3, pp. 190-197, 1999.

[83] J. Tong, "Incentives, term limits and the duty shirking of government officials," Journal of Guangdong University of Finance \& Economics, vol. 32, 2017, in Chinese.

[84] E. Herrfahrdt-Pähle, Two Steps Forward, One Step Back: Institutional Change in Kyrgyz Water Governance, Springer, Berlin, Germany, 2008.

[85] J. Shaoul, "The private finance initiative or the public funding of private profit?," in The Challenge of Public-Private Partnerships, vol. 69, no. 4, pp. 779-782, Edward Elgar Publishing, Cheltenham, UK, 2005.

[86] I. Kivleniece and B. V. Quelin, "Creating and capturing value in public-private ties: a private actor's perspective," Academy of Management Review, vol. 37, no. 2, pp. 272-299, 2012.

[87] J. Shaoul, "A critical financial analysis of the private finance initiative: selecting a financing method or allocating economic wealth?," Critical Perspectives on Accounting, vol. 16, no. 4, pp. 441-471, 2005.

[88] D. Zhen and F. Cao, "Theoretical research on PPP nature and value for money," Journal of Hebei University of Economics \& Business, vol. 39, 2018, in Chinese.

[89] Z. Chen, M. Zhang, and D. Si, "China's PPP practice: developments, models, problems and solutions," International Economic Review, no. 4, pp. 68-84, 2015, in Chinese.

[90] X. Zhou, "The road to collective debt in rural China," Modern China, vol. 38, no. 3, pp. 271-307, 2012.

[91] S. Q. Wang, R. L. K. Tiong, S. K. Ting, and D. Ashley, "Evaluation and management of foreign exchange and revenue risks in China's BOT projects," Construction Management and Economics, vol. 18, no. 2, pp. 197-207, 2000.

[92] B. Li, A. Akintoye, P. J. Edwards, and C. Hardcastle, "The allocation of risk in PPP/PFI construction projects in the UK," International Journal of Project Management, vol. 23, no. 1, pp. 25-35, 2005.

[93] G. Demuijnck, H. Ngnodjom, and Philosophy Documentation Center, "Public-private partnerships and corruption in developing countries," Business and Professional Ethics Journal, vol. 30, no. 3, pp. 253-268, 2011.

[94] P. Galilea and F. Medda, "Does the political and economic context influence the success of a transport project? An analysis of transport public-private partnerships," Research in Transportation Economics, vol. 30, no. 1, pp. 102-109, 2010.

[95] E. Iossa and D. Martimort, "Post-tender corruption and risk allocation: implications for public-private partnerships," Social Science Electronic Publishing, no. 195, 2011.

[96] E. Iossa and D. Martimort, The Economics of Public-Private Partnerships, University of Toulouse, Toulouse, France, 2007.

[97] I. Abramov, "Building peace in fragile states-building trust is essential for effective public-private partnerships," Journal of Business Ethics, vol. 89, no. S4, pp. 481-494, 2009.

[98] C. R. Rufin and M. Riverasantos, "Between commonweal and competition: understanding the governance of public-private partnerships," Journal of Management, vol. 38, no. 5, pp. 1634-1654, 2011.

[99] Y. Yang, Y. Hou, and Y. Wang, "On the development of public-private partnerships in transitional economies: an explanatory framework," Public Administration Review, vol. 73, no. 2, pp. 301-310, 2013.

[100] E. S. Savas, Privatization and Public-Private Partnerships, Chatham House Publishers, Inc., Chatham, NJ, USA, 2000. 
[101] Y. H. Kwak, Y. Chih, and C. W. Ibbs, "Towards a comprehensive understanding of public private partnerships for infrastructure development," California Management Review, vol. 51, no. 2, pp. 51-78, 2009.

[102] A. M. Abdel Aziz, "Successful delivery of public-private partnerships for infrastructure development," Journal of Construction Engineering and Management, vol. 133, no. 12, pp. 918-931, 2007.

[103] J. Pei and Z. Zeng, "Economic efficiency and political value: reflection on public-private partnerships (PPP)," Journal of Hebei University of Economics \& Busines, vol. 38, 2017, in Chinese.

[104] B. W. Hogwood and L. A. Gunn, Policy Analysis for the Real World, Oxford University Press, Oxford, UK, 1984.

[105] J. K. Roehrich, M. A. Lewis, and G. George, "Are publicprivate partnerships a healthy option? A systematic literature review," Social Science \& Medicine, vol. 113, no. 7, pp. 110-119, 2014.

[106] C. Chen, M. Hubbard, and C.-S. Liao, "When public-private partnerships fail," Public Management Review, vol. 15, no. 6, pp. 839-857, 2013.

[107] Z. Wang and X. Guo, "Risk identification and resolution of PPP project: from the perspective of incomplete contract," Reform, no. 6, 2018, in Chinese.

[108] S. Q. Wang, R. L. K. Tiong, S. K. Ting, and D. Ashley, "Foreign exchange and revenue risks: analysis of key contract clauses in China's BOT project," Construction Management and Economics, vol. 18, no. 3, pp. 311-320, 2000.

[109] A. P. C. Chan, J. F. Y. Yeung, C. C. P. Yu, S. Q. Wang, and Y. Ke, "Empirical study of risk assessment and allocation of public-private partnership projects in China," Journal of Management in Engineering, vol. 27, no. 3, pp. 136-148, 2011.

[110] M. M. Kumaraswamy and X. Q. Zhang, "Governmental role in BOT-led infrastructure development," International Journal of Project Management, vol. 19, no. 4, pp. 195-205, 2001.

[111] J. Warburton and G. Baker, "Integrity systems and local government," Australian Journal of Public Administration, vol. 64, no. 2, pp. 62-68, 2005.

[112] A. Ng and M. Loosemore, "Risk allocation in the private provision of public infrastructure," International Journal of Project Management, vol. 25, no. 1, pp. 66-76, 2007.

[113] A. Estache, E. Juan, and L. Trujillo, Public-Private Partnerships in Transport, Social Science Electronic Publishing, no. 29, Rochester, NY, USA, 2016.

[114] P. Gallimore, W. Williams, and D. Woodward, "Perceptions of risk in the private finance initiative," Journal of Property Finance, vol. 8, no. 8, pp. 164-176, 1997.

[115] X. Qi, Y. Ke, and S. Wang, "Analysis on critical risk factors causing the failures of China's PPP projects," China Soft Science, 2017, no. 5, in Chinese.

[116] M. A. Soomro and X. Zhang, "Evaluation of the functions of public sector partners in transportation public-private partnerships failures," Journal of Management in Engineering, vol. 32, no. 1, article 04015027, 2016.

[117] M. A. Soomro and X. Zhang, "Roles of private-sector partners in transportation public-private partnership failures," Journal of Management in Engineering, vol. 31, no. 4, article 04014056, 2013.

[118] A. P. C. Chan, P. T. I. Lam, D. W. M. Chan, E. Cheung, and Y. Ke, "potential obstacles to successful implementation of public-private partnerships in beijing and the Hong Kong special administrative region," Journal of Management in Engineering, vol. 26, no. 1, pp. 30-40, 2010.
[119] Y. Ke, S. Wang, A. P. C. Chan, and P. T. I. Lam, "Preferred risk allocation in China's public-private partnership (PPP) projects," International Journal of Project Management, vol. 28 , no. 5, pp. 482-492, 2010.

[120] N. F. Da Cruz and R. C. Marques, "Viability of municipal companies in the provision of urban infrastructure services," Local Government Studies, vol. 37, no. 1, pp. 93-110, 2011.

[121] A. E. Boardman and A. R. Vining, "Ownership and performance in competitive environments: a comparison of the performance of private, mixed, and state-owned enterprises," Journal of Law and Economics, vol. 32, no. 1, pp. 1-33, 1989.

[122] C. C. Ragin, The Comparative Method: Moving beyond Qualitative and Quantitative Strategies, University of California Press, Berkeley, CA, USA, 2014.

[123] R. Ahuja, A. Sawhney, and M. Arif, "Driving lean and green project outcomes using BIM: a qualitative comparative analysis," International Journal of Sustainable Built Environment, vol. 6, no. 1, pp. 69-80, 2016.

[124] A. Marx, P. C. Fiss, and B. Cambré, Chapter 2 Crisp-Set Qualitative Comparative Analysis in Organizational Studies, Emerald Group Publishing Limited, Bradford, UK, 2013.

[125] $\mathrm{H}_{2} \mathrm{O}$-China Lianjiang 45 Million Repurchase Zhongfatang Shanshui Factory, http://www.h2o-china.com/news/85088. html, in Chinese.

[126] G. Atmo and C. Duffield, "Improving investment sustainability for PPP power projects in emerging economies," Built Environment Project and Asset Management, vol. 4, no. 4, pp. 335-351, 2014.

[127] L. Wang and X. Zhang, "Bayesian analytics for estimating risk probability in PPP waste-to-energy projects," Journal of Management in Engineering, vol. 34, no. 6, article 04018047, 2018.

[128] C. Sanitation Qinhuangdao western waste incineration power generation project is deadlocked, http://www.cn-hw. net/html/china/201207/34297.html, in Chinese.

[129] P E O China Wuxi waste disposal puzzle survey: why the waste incineration plant built by huge capital is idle, http:// news.bjx.com.cn/html/20140703/524141.shtml, in Chinese.

[130] L. Wang and X. Zhang, "Critical risk factors in PPP waste-toenergy incineration projects," International Journal of Architecture, Engineering and Construction, vol. 6, no. 2, pp. 55-69, 2017.

[131] Y. Xu, A. P. C. Chan, B. Xia, Q. K. Qian, Y. Liu, and Y. Peng, "Critical risk factors affecting the implementation of PPP waste-to-energy projects in China," Applied Energy, vol. 158, pp. 403-411, 2015.

[132] Y. Ke, S. Wang, and A. P. C. Chan, "Risk management practice in China's public-private partnership projects," Journal of Civil Engineering and Management, vol. 18, no. 5, pp. 675-684, 2012.

[133] People.cn Hengshanqiao sewage treatment plant becomes a source of pollution, http://js.people.com.cn/html/2012/02/ 19/80725.html, in Chinese.

[134] Y. Xu, Y. Yang, A. P. C. Chan, J. F. Y. Yeung, and H. Cheng, "Identification and allocation of risks associated with PPP water projects in China/su kinijos vandens projektais, pagrịstais viešojo Ir privačiojo sektoriụ partneryste, susijusiụ rizikos rūšių nustatymas Ir paskirstymas," International Journal of Strategic Property Management, vol. 15, no. 3, pp. 275-294, 2011.

[135] $\mathrm{H}_{2} \mathrm{O}$-China Wuhan Tangxun lake wastewater treatment plant BOT project terminated, http://www.h2o-china.com/ news/31245.html, in Chinese. 
[136] P. C. O. S. Province Hancheng sewage treatment plant and supporting pipe network PPP project, http://jrc.sf.gov.cn/ info/1006/1052.html, in Chinese.

[137] Bridata national PPP integrated information database, http:// www.bridata.com/t\#/tools, in Chinese.

[138] S. Hoard, "Gender expert success in public policy: towards a better understanding," in Gender Expertise in Public Policy, pp. 167-179, Springer, Berlin, Germany, 2015.

[139] G. Albort-Morant and P. Oghazi, "How useful are incubators for new entrepreneurs?," Journal of Business Research, vol. 69, no. 6, pp. 2125-2129, 2016.

[140] D. De Smet, A.-L. Mention, and M. Torkkeli, "Involving high net worth individuals (HNWI) for financial services innovation," Journal of Financial Services Marketing, vol. 21, no. 3, pp. 226-239, 2016.

[141] Y. Ueki, "Customer pressure, customer-manufacturer-supplier relationships, and quality control performance," Journal of Business Research, vol. 69, no. 6, pp. 2233-2238, 2016.

[142] L. M. Mastrangelo, D. G. Benitez, and S. Cruz-Ros, "How social entrepreneurs can influence their employees' commitment," Journal of Promotion Management, vol. 23, no. 3, pp. 437-448, 2017.

[143] C. C. Ragin, "Set relations in social research: evaluating their consistency and coverage," Political Analysis, vol. 14, no. 3, pp. 291-310, 2006.

[144] B. Grofman and C. Q. Schneider, "An introduction to crisp set QCA, with a comparison to binary logistic regression," Political Research Quarterly, vol. 62, no. 4, pp. 662-672, 2009.

[145] T. S. Council the general office of the state council on the proper handling of existing guarantees notice on issues related to investment in fixed return projects, http://www.gov. cn/gongbao/content/2002/content_61783.html, in Chinese. 


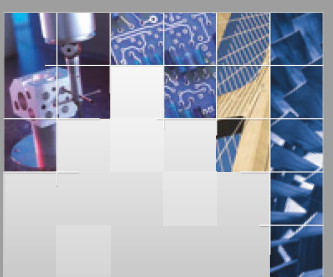

\section{Enfincering}
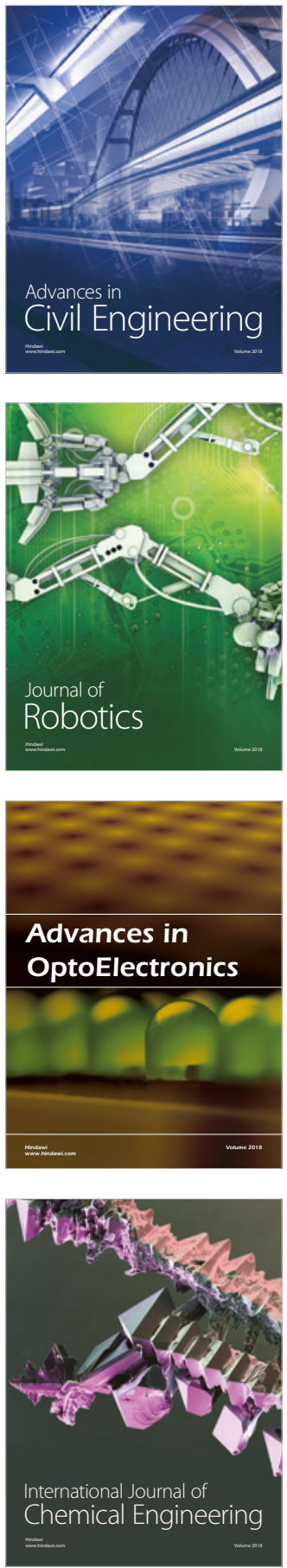

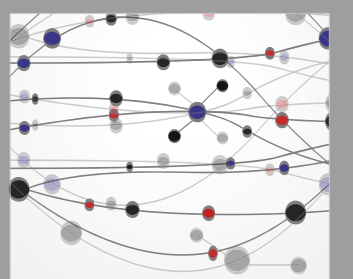

\section{Rotating \\ Machinery}

The Scientific World Journal

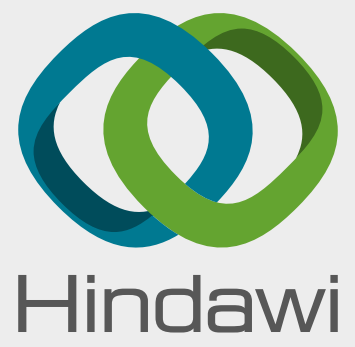

Submit your manuscripts at

www.hindawi.com
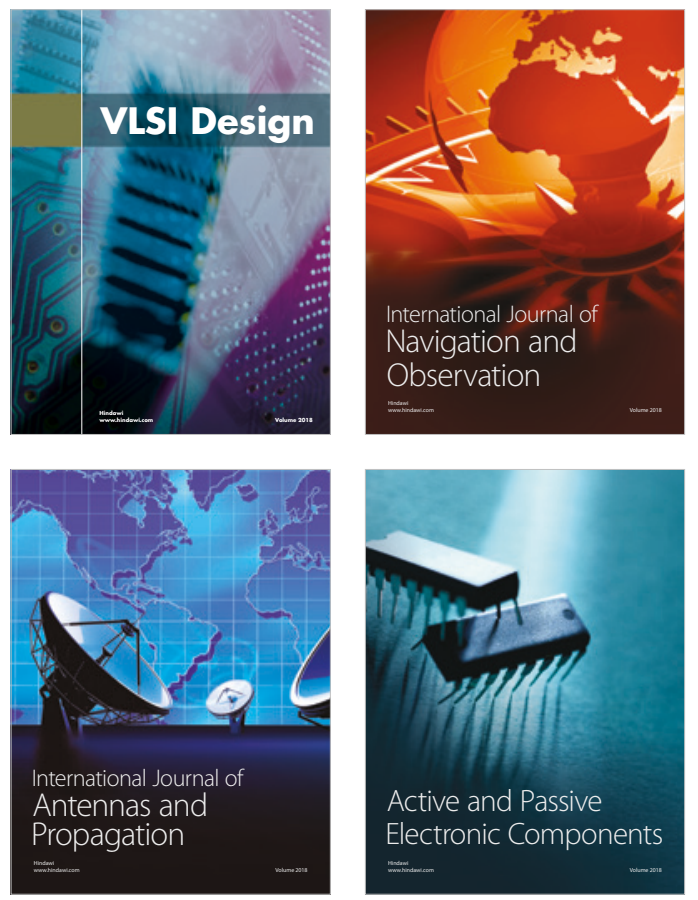
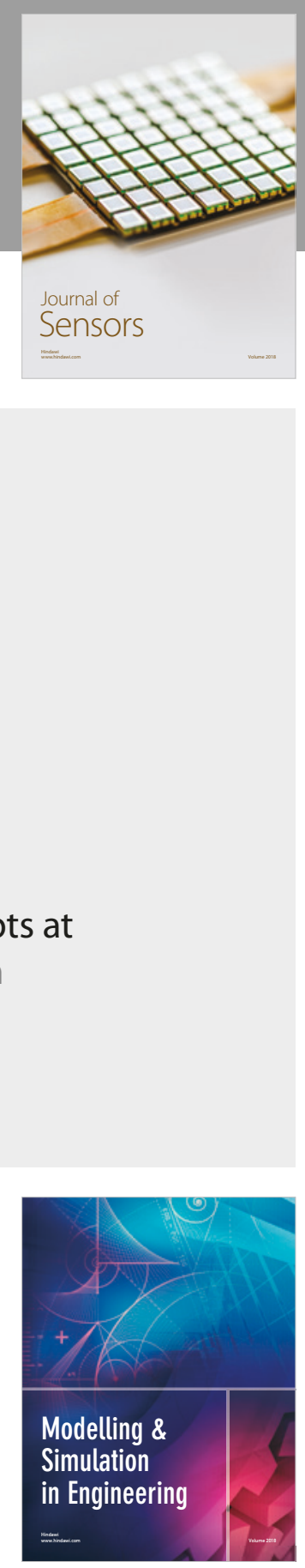

\section{Advances \\ Multimedia}
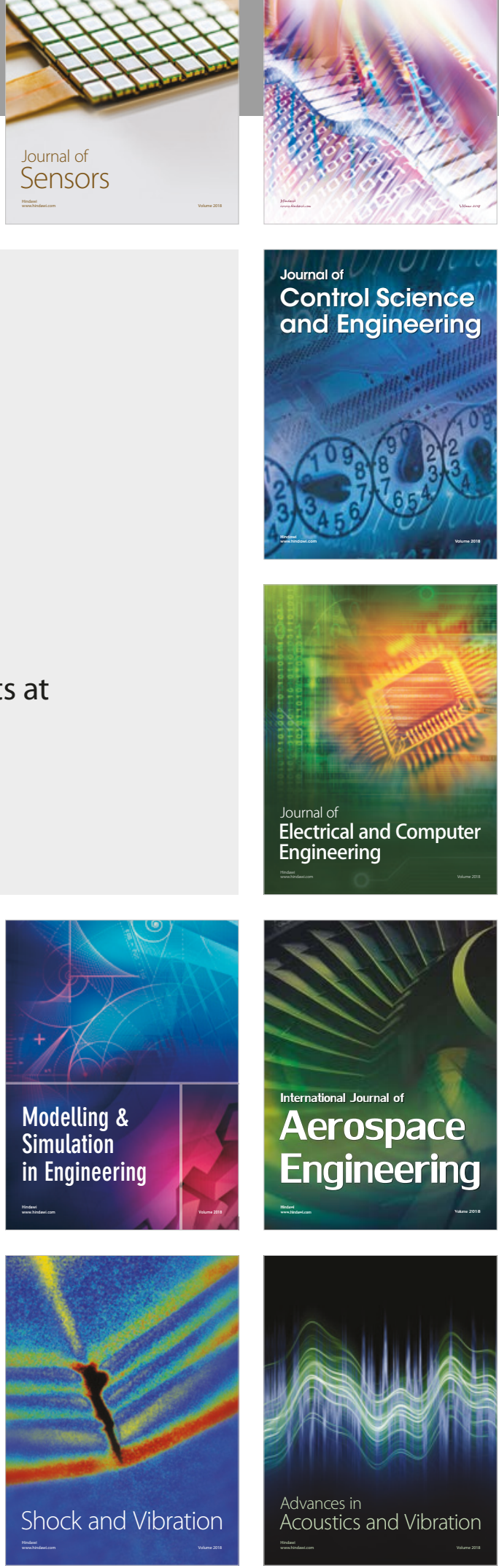